\title{
Testimonios y emociones narradas y fotografiadas en la enciclopedia de migrantes
}

\author{
Histories and emotions narrated and photographed in the \\ encyclopedia of migrants
}

\author{
Ángel Belzunegui-Eraso \\ Universidad Rovira i Virgili \\ Juan Antonio Roche Cárcel \\ Universidad de Alicante \\ ja.roche@ua.es (ESPAÑA)
}

Recibido: 21.122018

Aceptado: 16.04.2020

"Todas las sociedades están llenas de emociones" (Nussbaum, 2014: 13).

\section{RESUMEN}

En este artículo se analiza una selección de cartas escritas por migrantes y de imágenes fotográficas realizadas a ellos y recogidas en la obra Enciclopedia de los Migrantes, fruto de una investigación y de la creación artística financiado por la UE y elaborado simultáneamente en 8 ciudades de Francia, España, Portugal y Gibraltar. Las cartas están dirigidas a una persona que quedó en su tierra de procedencia y explican sus vivencias personales, sus emociones, sentimientos y percepciones en relación al proceso migratorio. Las imágenes fueron realizadas por un fotógrafo artístico bajo la premisa de que tanto el escenario como los objetos retratados fueran elegidos por la propia persona migrante. Los retratos realizados fueron concebidos como una clase de etnofotografia, en la que se analiza tanto las imágenes y sus contenidos (mediante el método de análisis iconológico), particularmente la concepción del cuerpo y de las emociones de los migrantes. I 


\title{
PALABRAS CLAVE
}

Migración; Emociones; Análisis iconológico; Análisis multinivel; Identidad.

\begin{abstract}
This article analyzes a selection of letters written by migrants and photographic images made to them, and collected in the work Encyclopedia of Migrants. The work is the result of research funded by the EU and developed, simultaneously, in 8 cities in France, Spain, Portugal and Gibraltar. The letters are addressed to a person who stayed in their homeland and explain their personal experiences, their emotions, feelings and perceptions regarding the migratory process. The images were made by an artistic photographer under the premise that both the stage and the objects portrayed were chosen by the migrant himself. The portraits were conceived as a kind of ethnophotography in which the images and their contents are analyzed simultaneously (through the method of iconological analysis), particularly the conception of the body and the emotions of the migrants.
\end{abstract}

\section{KEY WORDS}

Migration; Emotions; Iconological analysis; Multilevel analysis; Identity.

\section{INTRODUCCIÓN: LA ENCICLOPEDIA DE LOS MIGRANTES}

La Enciclopedia de los Migrantes ${ }^{1}$ (EM, en adelante) es un proyecto de investigación artística y sociológica en la que participaron científicos sociales, artistas y trabajadores/educadores sociales de ocho ciudades europeas, con la idea de dar voz a las personas migrantes ${ }^{2}$. Su contenido consiste en reunir, en una enciclopedia, 400 testimonios de los migrantes en forma de carta y una fotografía/retrato de los protagonistas en ocho ciudades de la costa atlántica de Europa entre Gibraltar y el bretón de Finisterre: Brest, Rennes y Nantes (en Francia),

${ }^{1}$ Nota legal para la utilización de los materiales de la L'Encyclopédie: "L'Encyclopédie des migrants - www.encyclopedie-des-migrants.eu - proyecto de cooperación europea coordinado por L'âge de la tortue, a iniciativa de la artista Paloma Fernández Sobrino". Esta investigación fue financiada por la UE a través del programa Erasmus + y contó con el apoyo del Institut Français, el Ayuntamiento de Rennes, Rennes Métropole, el Consejo General de Ille-et-Vilaine, el Consejo Regional de Bretaña, el Contrato Urbano de Cohesión Social, el Ministerio de Cultura y comunicación - Dirección Regional de Asuntos Culturales de Francia y la Fondation SNCF. Para conocer mejor el proyecto, se puede acceder libremente al sitio: http://www.encyclopedie-des-migrants.eu.

${ }^{2}$ El concepto de migrante significa aquí toda persona que ha experimentado un proceso migratorio. 
Gijón y Cádiz (en España), Oporto y Lisboa (en Portugal) y Gibraltar. El objetivo principal del proyecto ha sido narrar una historia íntima de la experiencia emocional de personas migrantes. El proyecto se llevó a cabo entre 2014 y 2017.

EM utilizó la imagen de la histórica Encyclopédie para (re)presentar un recopilatorio de historias/imágenes de la migración en primera persona. Así, se quiso utilizar un "contenedor" del saber canónico para "vaciarlo" y presentar otros saberes nacidos de la experiencia migratoria. Por consiguiente, la EM no es un proyecto que habla de los migrantes, sino uno en el que los migrantes hablan.

Por otra parte, la EM se sale de los cánones de la investigación social para articular un diseño en el que la Sociología, la Antropología, el Arte y el Trabajo Social dialogan para crear un nuevo marco de investigación. De este modo, se generó un saber de abajo arriba fundamentado en las historias cotidianas. Por un lado, la EM supuso una reflexión metodológica participativa entre diferentes actores, por otro esta estrategia metodológica, vinculada con la fotografía documental, combina testimonios de las personas migrantes (cartas, relatos breves producidos por ellas mismas que reflejan sus emociones, sus condiciones de vida, sus sentimientos...), que son compartidos con una persona que ellas eligen y que está en otro lugar del mundo, con la obra fotográfica (retratos acordados entre la persona protagonista y un fotógrafo profesional ${ }^{3}$ ).

No en balde, la EM no fue un proyecto de investigación al uso, pues no se priorizó un plan de análisis preconcebido para evitar que todo se ajustara a dicho plan o para diluir la tensión entre el sujeto convertido en objeto de estudio y el investigador. Y es que concebir la realidad social como algo dado y externo al sujeto proyecta imágenes planas externas a manera de una cámara estenopéica, por lo que, para superar esta forma de (re)producir la realidad, la EM se propuso captar la dimensión poliédrica de la migración.

\section{EL ESTUDIO DE LAS EMOCIONES EN LOS MIGRANTES}

Cabe también indicar que no se prodigan los análisis sociológicos que tomen las emociones como objeto de estudio, en cuanto éstas se consideren como una vía de acceso clave para el conocimiento de los fenómenos sociales, tal como sostiene Hochschild (1981). Kemper (1978), sin embargo, entiende que la mayor parte de las emociones tienen sentido en el marco de nuestras relaciones sociales. En este sentido, para Nussbaum (2014: 33), las emociones "implican necesariamente valoraciones cognitivas, formas de percepción y/o pensamiento cargadas de valor y dirigidas a un objeto u objetos". En esta línea argumental,

${ }^{3}$ En total han sido ocho los fotógrafos, uno por cada ciudad, que han participado en el proyecto. Resumir sus curricula aquí desbordaría las páginas con las que contamos. Evidentemente, estos fotógrafos han seguido su criterio profesional, pero en un abierto diálogo con los protagonistas, de manera que han trasladado al lenguaje visual los deseos de los migrantes. De ahí que, en la metodología del análisis iconológico que aparece más adelante, se hayan incorporado también aspectos relacionados con el Framing Visual, oportunos -como se verá- para recoger las intenciones del artista. 
Bericat (2000: 145) sostiene que resultaría inconcebible un actor social cuyo universo simbólico estuviera exclusivamente compuesto de ideas o cogniciones, al margen de las emociones, pues éstas serían el reflejo, la condición y el substrato último de toda reflexividad humana y social, y también de todo pensamiento y actividad mental y física. Al menos esto es lo que sostienen los trabajos del neurocientífico Damasio $(1995,2005)$, quien ha demostrado la importancia de los sentimientos y de las emociones en la vida de los individuos.

En concreto, trataremos aquí, fundamentalmente, de las "emociones secundarias", que presentan un componente cognitivo más alto que las primarias (como el miedo, la ira, la alegría, la tristeza, el disgusto y la sorpresa) y que, además, van siempre asociadas a las relaciones interpersonales y a las experiencias subjetivas -a los sentimientos- (Belmonte, 2007), como la nostalgia, la incertidumbre, la culpa, la vergüenza o el desasosiego.

Al lado de estas lecturas académicas, el análisis de las cartas y las imágenes permite conocer los estados de los migrantes en términos de percepciones, emociones y sentimientos, y muestran las heridas de la migración -la frustración, la inquietud, el miedo, el dolor, el desencanto, el desarraigo, el sentimiento de culpa...-, y sus antagónicas -el logro, la añoranza, la libertad, la seguridad, el arraigo, la felicidad, la dignidad, el respeto...--

En suma, los sentimientos y las emociones expresadas denotan que no son un absoluto biológico, sino que se entienden como el resultado de las experiencias sociales de los sujetos y que se configuran dentro de marcos mentales que generan, a su vez, las distintas experiencias migratorias. Tal como afirma Martín Criado (2014: 120), "los sujetos rara vez actúan en situaciones similares a aquellas donde fueron socializados, ya sea por el continuo cambio social o por rupturas en las trayectorias biográficas individuales", como por ejemplo la migración. Así, las emociones expresadas se manifiestan como refuerzos positivos o negativos de estas experiencias, que tienen que ver también con los riesgos que encierra el hecho migratorio, tal y como se externalizan en el documental $E l$ tren de la memoria (2012), que recoge las experiencias migratorias de españoles en Alemania en los años sesenta y setenta del siglo XX. De hecho, el proyecto migratorio puede ser englobado como uno de los momentos que tiene una especial relación con el riesgo. Al respecto, como afirma Giddens (1997: 147), "Hay momentos en que el individuo debe poner rumbo a algo nuevo, a sabiendas de que una decisión que tome o una dirección que siga tendrá la calidad de lo irreversible o que, al menos, le será luego difícil volver al antiguo sendero".

Los materiales aquí presentados ponen de relieve que, por un lado, "los sujetos [los migrantes] no tenemos personalidades integradas en torno a una cultura internalizada coherente: somos sujetos plurales, con disposiciones heterogéneas. Por otro, hay un desajuste entre las condiciones en que fuimos socializados y aquellas en que actuamos" (Martín Criado, 2014: 125). 


\section{LA METODOLOGÍA UTILIZADA}

\subsection{La muestra}

Para la muestra estructural, las personas fueron seleccionadas a través del análisis de campo, ya que los participantes del estudio eran desconocidos. Como método de contacto se siguió la técnica de la bola de nieve. La selección de las observaciones mediante la variable explicativa (ser migrante) no produce problemas inferenciales debido a que el procedimiento de selección no predetermina el resultado del estudio (King, Keohane y Verba, 2000). Para evitar sesgos, se tuvieron en cuenta variables de control como el sexo, la edad y el lugar de origen. Se seleccionaron 400 personas procedentes de 100 países, 50 en cada ciudad. Las cartas se escribieron en 72 idiomas nativos y fueron traducidas al castellano, francés, portugués e inglés, por un servicio de traducción homologado. Los migrantes fueron invitados a escribir una carta dirigida a una persona de su país de origen (en el caso de que se tratara de retornados, a alguien que quedó en su anterior país de residencia). La entidad social que trabajó en cada ciudad se encargó de la selección de los 50 participantes y un contacto (un investigador social) sirvió de enlace entre la entidad y la persona migrante. Se necesitó un tiempo para establecer una relación de confianza y de cooperación en el proyecto. Las personas migrantes entregaron los documentos epistolares a este contacto. Al mismo tiempo, la entidad social de la ciudad que participa en el proyecto seleccionó un/a artista fotográfico que estableció una relación con la persona migrante y, entre los dos, acordaron cómo sería la representación de su persona.

En la muestra, el 44,4\% son hombres y, el 55,6\%, mujeres. Un 54,9\% tiene entre 30 y 59 años; un $28,1 \%$ hasta 30 años y, el 16,9\%, más de 59 años. Un $29,8 \%$ es de África, el 22\% de Latinoamérica, el 1,7\% de Norteamérica (EEUU y Canadá), el 14,2\% de Asia y, el 32,2\%, de Europa.

\subsection{El análisis}

El análisis de las cartas siguió el modelo de Análisis Cualitativo Multinivel (ACM) (Belzunegui et al., 2012). La primera fase, la categorización textual, permitió construir una matriz de datos con las unidades de análisis (las cartas y los sujetos) y las variables resultantes de la categorización de la información, más otras de tipo sociodemográfico. El proceso de categorización de los textos se realizó con el programa Weft QDA, y las categorías utilizadas fueron: Miedo; Inquietud/angustia; Añoranza/nostalgia; Tristeza; Soledad; Racismo/discriminación; Desarraigo; Pobreza/miseria; Sacrificios; Solidaridad; Superación/esfuerzo; Felicidad; Amor; Amistad; Esperanza; Libertad; Crecimiento personal; Se siente integrado; Progreso personal. Todas ellas variables binarias, $0=$ no reporta, $1=$ sí reporta. En la segunda fase, el Nivel Estructural Relacional, se produjeron los datos descriptivos y relacionales procedentes del cruce de algunas variables. Por 
último, en la fase del Nivel Social-Hermenéutico, se aplicó un análisis interpretativo de las cartas e imágenes.

\subsection{El análisis iconológico}

En esta última fase, complementando y contrastando los significados de las cartas, se realizó un "análisis iconológico" o "iconográfico" de un total de 24 fotografías, seleccionadas, del total de las efectuadas, buscando que éstas fueran suficientemente representativas y significativas de las emociones de los migrantes. Las que han quedado fuera lo han sido porque, o bien repetían asuntos temáticos, o bien porque no añadían nada nuevo que no estuviera presente en las fotografías que sí han sido interpretadas. Estas últimas, han sido relacionadas con las cartas que los migrantes han enviado a sus personas cercanas.

En cuanto al "análisis iconológico" o "iconográfico", constituye un método de larga tradición sociológica (González García, 1998: 23-43), heredado de E. Panofsky. Este historiador del arte, en Estudios sobre iconología y en El significado de las artes visuales, afirma que el análisis iconológico posee tres niveles de significación: en el primero, se describen los elementos que conforman la obra, la lógica racional de la imagen podría decirse, esto es, cómo se relacionan entre sí los diferentes elementos que la conforman -los personajes, los objetos, los paisajes, las acciones, los gestos...-; en el segundo, se reconocen los valores simbólicos; $y$, en el tercero, se alcanza el significado intrínseco superador de la voluntad consciente del artista -del fotógrafo- (Panofsky, 1972: 15; 2014: 45-8). Además, este nivel persigue el objetivo de hallar significados en las profundidades de su inconsciente, lo que requiere la investigación y la fundamentación en documentos y en fuentes adyacentes a la obra y al propio artista -el fotógrafo-, y al tiempo en el que despliega su trabajo.

Así pues, por debajo de la racionalidad de la fotografía, se halla su logos -su discurso-, es decir, la ideología del fotógrafo que ésta ampara. La ideología se considera aquí, siguiendo a Van Dijk, como un sistema de ideas, valores y preceptos que organizan o legitiman las acciones de los individuos o de los grupos. El discurso, por su parte, es el modo de acción y de interacción social ubicado en contextos sociales, esto es, que tanto él como sus dimensiones mentales (sus significados, por ejemplo) se inscriben en situaciones y en estructuras sociales (Van Dijk, 1998:16-19). Por tanto, la singular selección fotográfica del universo de los migrantes y del territorio que habitan expresa, además de su concreta problemática, su ideología y su discurso.

Este método de la historia del arte también fue empleado y perfilado por K. Mannheim (Barboza, 2005: 348-351), aunque él lo llama "el método documental", un modelo ejemplar para analizar la imagen en la Sociología. Y es que, con él, el interés del sociólogo se dirige a la información social que ofrecen las imágenes, al considerarlas como "documentos de una actitud emocional peculiar al período o la sociedad en la que fue producida" y como evidencias de la "singularidad de un grupo social o de una época determinada". Además, para Mannheim, 
el método de interpretación documental posee -como en Panofsky- tres niveles de sentido: el objetivo (la representación de cosas o de una situación), el expresivo (la intención del autor; él único sentido distinto al señalado por Panofsky) y el documental (una determinada concepción del mundo).

En suma, el análisis iconológico de las fotografías de los migrantes busca el significado que esconden en relación a las emociones que experimentan en sus traslados y, ello, con el fin de convertirlas en unos documentos sociales, teniendo en cuenta tanto la propia imagen como su contexto y la intención del fotógrafo. Por consiguiente, la fotografía desvelada mediante el análisis iconológico -el método documental- representa un dato sociológico y discursivo que expresa un alcance oculto, ontológico, ético, político, estético y sociológico.

Por otra parte, el análisis iconológico muestra puntos de contacto con el Framing visual, originario del ámbito de la comunicación, otra metodología útil para nuestro propósito, no en balde los elementos visuales ligan la Sociología al género periodístico (Barboza, 2005: 347). Concretamente, este método hace un encuadre visual de la realidad, enmarca la información. Y, aunque se halla aún en un nivel inicial de conocimiento sin que todavía exista una definición única del mismo, nos parece apropiado cómo lo caracteriza Entman: el proceso de encuadre conlleva la selección de "algunos aspectos de la realidad percibida, haciéndolos más sobresalientes..., de tal manera que consiguen promover una definición del problema particular, una interpretación causal, una evaluación moral y/o una recomendación de tratamiento para el asunto descrito". Mientras que el concepto de encuadre se refiere al "ángulo, enfoque, perspectiva o tratamiento de una información que se manifiesta en la elección, énfasis o importancia atribuida a los diferentes elementos" (Muñiz et al, 2006: 106-7; López y Humanes, 2016: 88).

Por lo demás, en el análisis fotográfico del Framing visual, se utilizan tres grandes categorías: el contexto físico-espacial en el que transcurren los acontecimientos mostrados -los lugares que habitan o transitan los migrantes-; el contexto humano, las personas descritas en las imágenes -los migrantes-; y los rasgos fotográficos que atañen al modo en el que se representan tanto el contexto físicoespacial como el humano -los encuadres, los planos, la luz, los colores...- (López y Humanes, 2016: 91). Igualmente, son tres los niveles de análisis que efectúa y que forman un continuum descriptivo/explicativo/interpretativo (Casanova y Massó, 2018: 111), o como indican otros autores, iconográfico (descriptivo), iconológico (interpretativo) y ético (implicativo) (De Andrés et al, 2016: 31).

Como se ve, las semejanzas entre el análisis iconológico, el método documental de Mannheim y el Framing visual son profundas y podrían resumirse en la interacción existente entre tres niveles de la realidad: el mundo (los migrantes, los objetos que les rodean y el espacio en el que se desenvuelven), la fotografía y la intención del fotógrafo. Con estos tres niveles, analizaremos las fotografías seleccionadas.

Pero nos gustaría añadir, para terminar esta parte metodológica, algunas cuestiones que perfilan algo más el tipo de Sociología visual empleado y, concretamente de Sociología de la fotografía. Ante todo, cabe decir que, a pesar de 
ciertos excelentes antecedentes sociológicos (Bourdieu, et al., 1965: 36; Goffman, 1979: 84; Becker, 1981: 96; Becker, 1982: 392; De Miguel y Ponce de León, 1998; Huici y Dávila, 2019), la Sociología visual está todavía en mantillas y caben, por tanto, exploraciones que enriquezcan el panorama; humildemente, nosotros pretendemos que nuestra aportación ensanche algo más este camino.

Eso sí, consideramos que la fotografía constituye una herramienta del análisis social que contribuye sustancialmente a la construcción de la realidad social (De Miguel y Ponce de León, 1998: 84-6). En este sentido, el lenguaje visual nos coloca en un plano de relaciones comunicacionales mucho más horizontal y simétrico con el objeto de investigación, pues permite un conocimiento "empático" y un discurso alternativo sobre la migración y lo hace -como se verá aquídesde la perspectiva de los propios actores implicados (Aguilar, 2011: $100 \mathrm{ss}$ ). Además, la carga emotiva que porta la fotografía siempre es mucho mayor que la de cualquier texto escrito y, por consiguiente, ayuda a humanizar los problemas sociales (López y Humanes, 2016: 88), en este caso de los migrantes, es decir, que los acerca a los espectadores convirtiéndolos en seres humanos individuales, sufrientes y luchadores y no tanto en abstracciones generalizadoras.

También quisiéramos señalar que la interpretación de estas imágenes no puede dejar de ser histórica, en la medida en que depende del conocimiento previo que se tiene de la situación y de que se hicieron un tiempo después de la experiencia migratoria (De Andrés et al, 2016: 35), y de cientos de artículos y publicaciones.

Finalmente, el tipo analizado en este artículo es el de la fotografía documental, que, junto con el fotoperiodismo y la fotosociología, representa un género de imagen informativa que nos permite conocer el mundo (Becker, 1981: 96; 1982: 392). Así, al ser los fotógrafos documentalistas los que "tienen que producir imágenes claras, inmediatamente comprensibles, interpretables y descriptivas" (Bericat, 2012: 203-4), sus obras devienen un documento social de primer nivel, una fuente de información imprescindible para otorgarle una imagen -afectiva- a la realidad de estos seres humanos que han experimentado una situación límite.

\section{LOS RESULTADOS}

El miedo y el pasar inquietudes y angustias no presentan diferencias significativas en las cartas escritas por los migrantes seleccionados. La nostalgia es la emoción más extendida, pues la reporta un 51,9\% de ellos. La tristeza, (señalada por el 19,3\% del total) está más presente en los asiáticos, en el 33,3\%. La soledad aparece en un 12,5\% de las cartas. Un 9,8\% reporta racismo y/o discriminación, concretamente en un 6,7\% de las mujeres frente a un $13,7 \%$ de los hombres y en un $20,5 \%$ de africanos frente al 2,1\% de europeos. El desarraigo lo expresa un $3,4 \%$. Un $4,4 \%$ del total destaca la pobreza (hombres, $8,2 \%$; mujeres, $2,8 \%$ ) siendo los africanos y los asiáticos los que más la señalan. Le siguen los sacrificios $(11,9 \%)$ y el esfuerzo $(30,2 \%)$, aunque también aparecen la felicidad (15,9\%), el amor (14,6\%), la amistad (26,8\%), la esperanza $(21,7 \%)$ y 


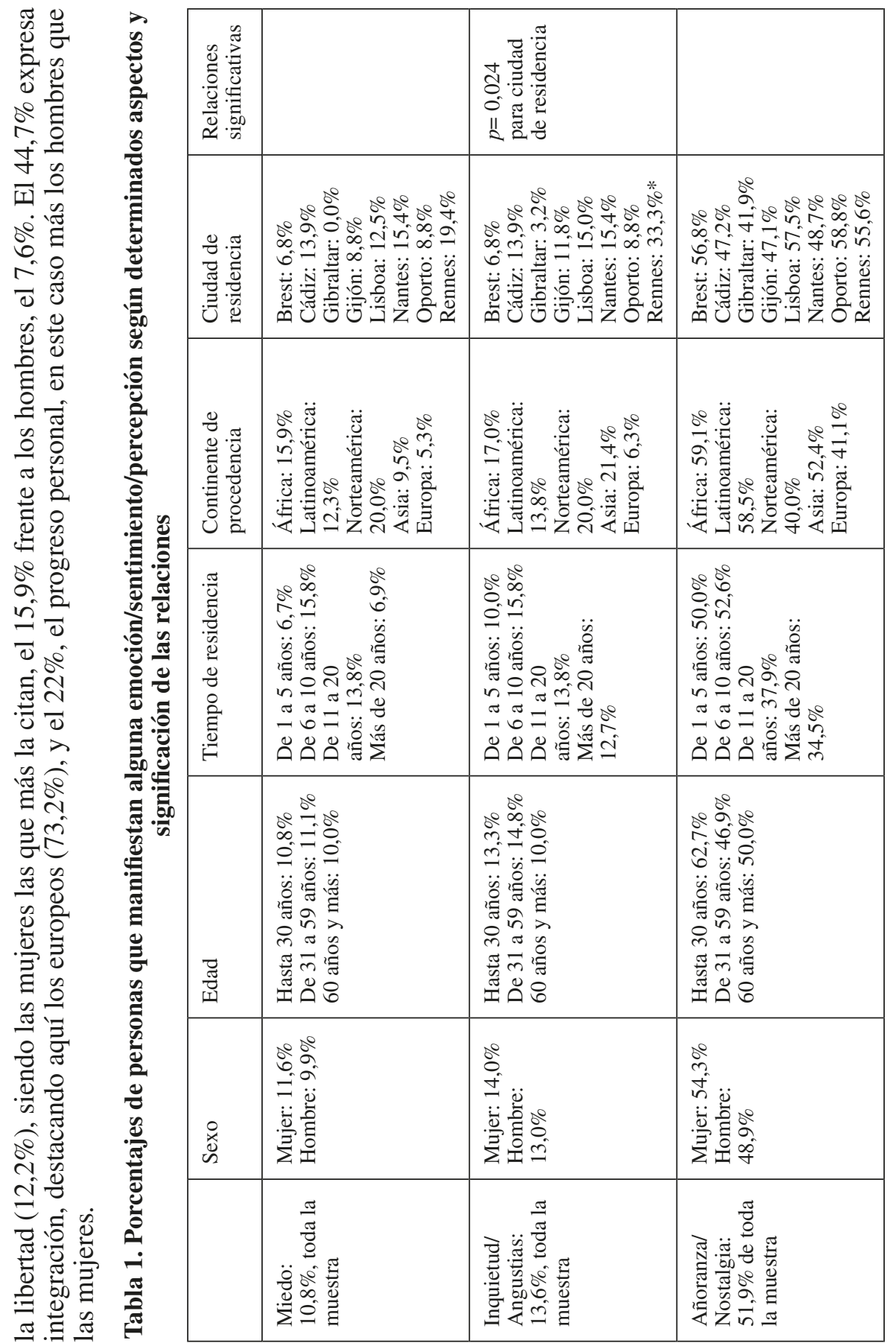




\begin{tabular}{|c|c|c|c|c|}
\hline 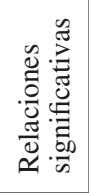 & 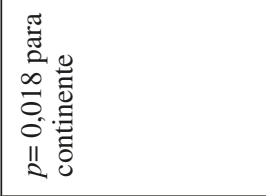 & & 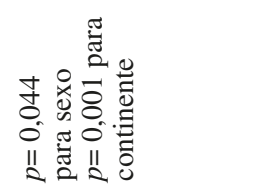 & \\
\hline 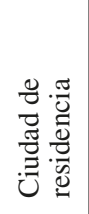 & 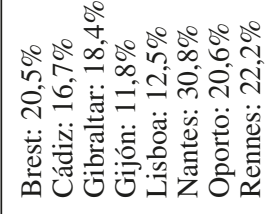 & 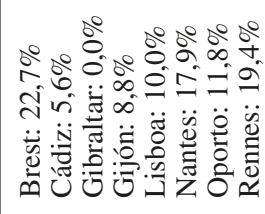 & 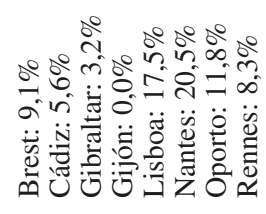 & 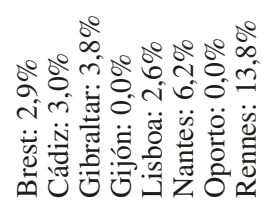 \\
\hline 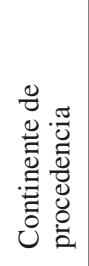 & 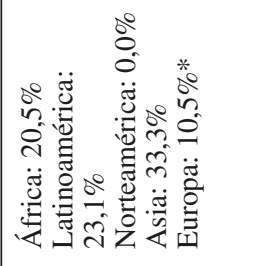 & 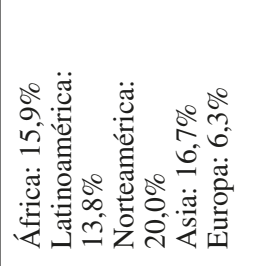 & 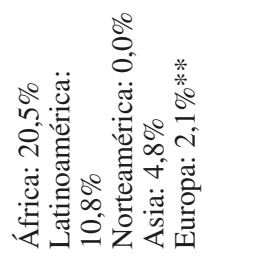 & 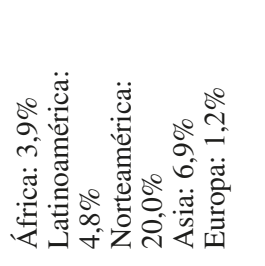 \\
\hline 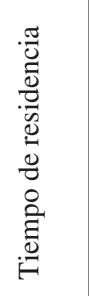 & 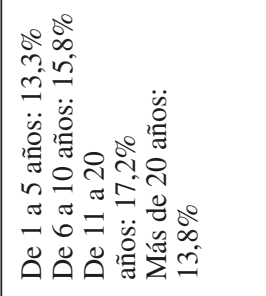 & 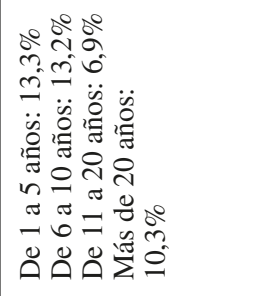 & 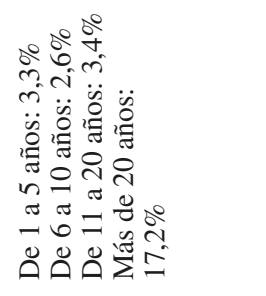 & 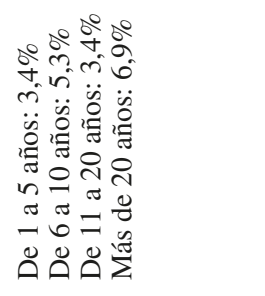 \\
\hline $\begin{array}{l}\overrightarrow{\tilde{J}} \\
\text { I }\end{array}$ & 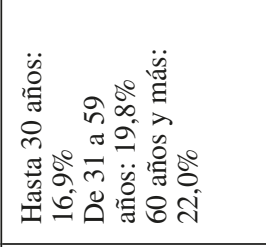 & 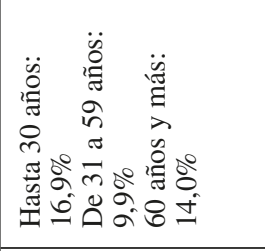 & 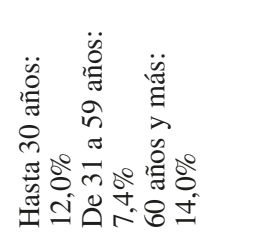 & 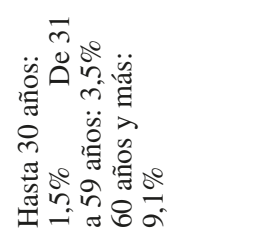 \\
\hline 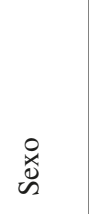 & 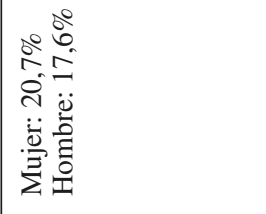 & 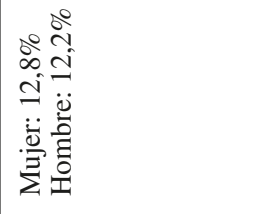 & 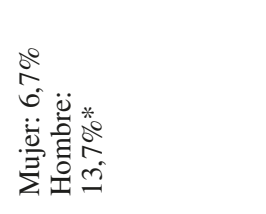 & 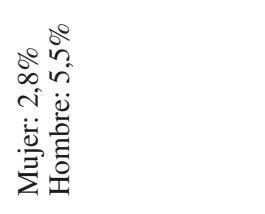 \\
\hline & 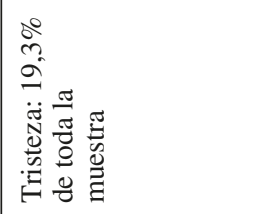 & 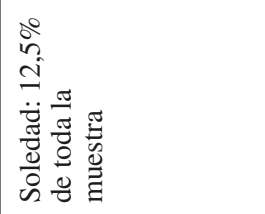 & 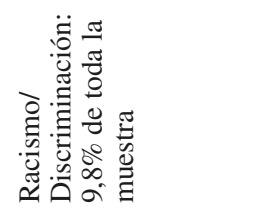 & 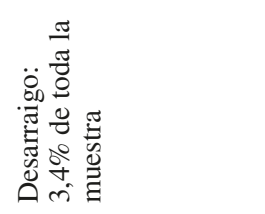 \\
\hline
\end{tabular}




\begin{tabular}{|c|c|c|c|}
\hline 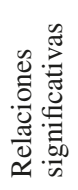 & 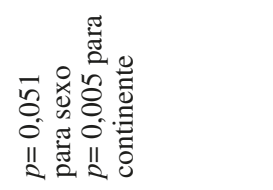 & 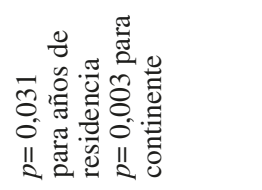 & 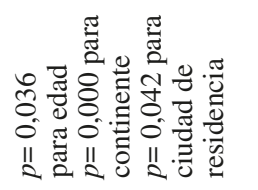 \\
\hline 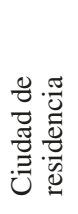 & 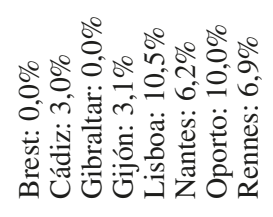 & 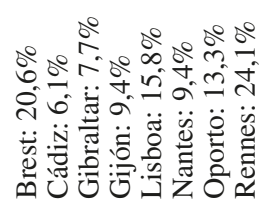 & 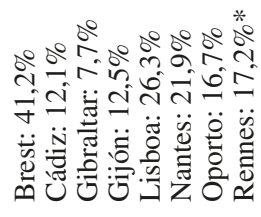 \\
\hline 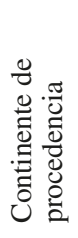 & 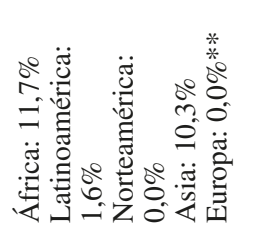 & 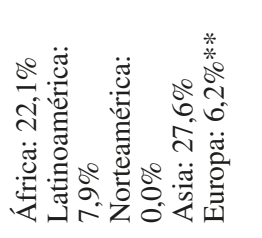 & 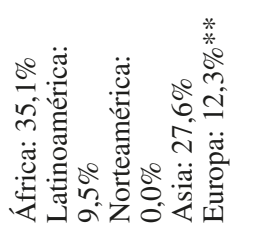 \\
\hline 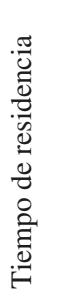 & 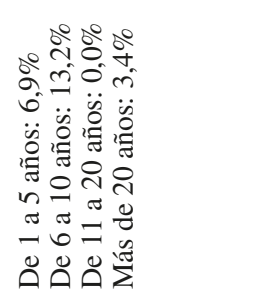 & 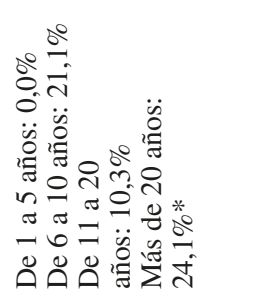 & 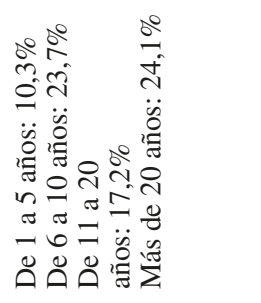 \\
\hline 苞 & 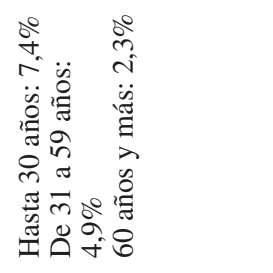 & 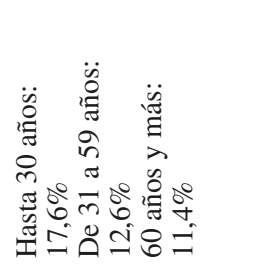 & 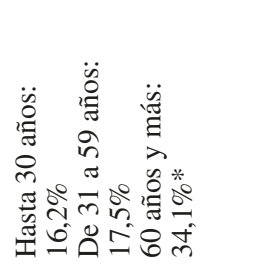 \\
\hline $\begin{array}{l}0 \\
\ddot{x} \\
\tilde{n}\end{array}$ & 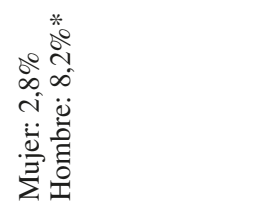 & 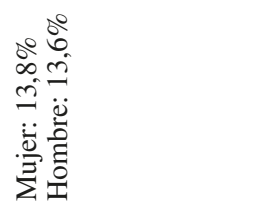 & 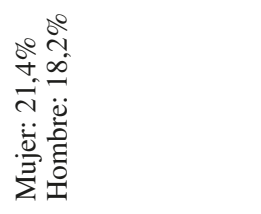 \\
\hline & 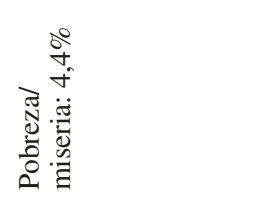 & 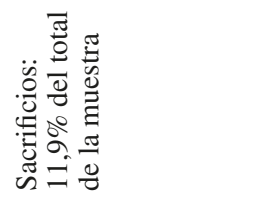 & 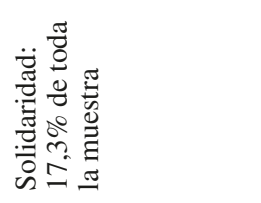 \\
\hline
\end{tabular}




\begin{tabular}{|c|c|c|c|c|}
\hline 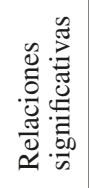 & & 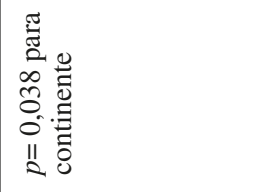 & 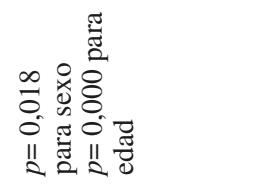 & 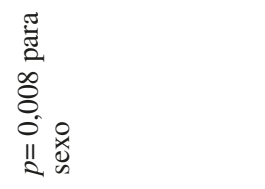 \\
\hline 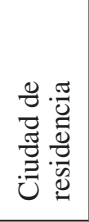 & 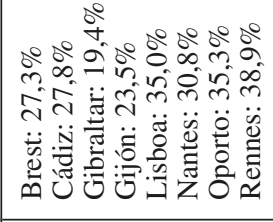 & 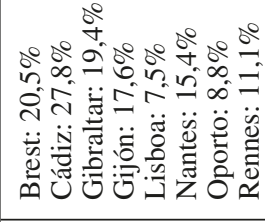 & 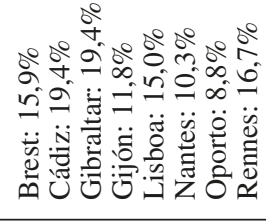 & 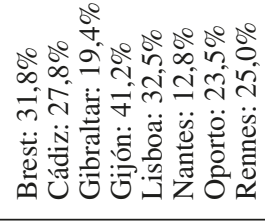 \\
\hline 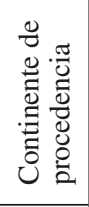 & 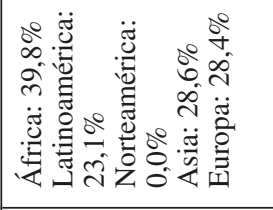 & 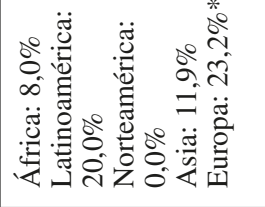 & 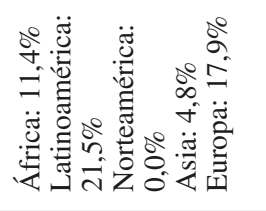 & 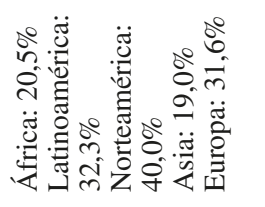 \\
\hline 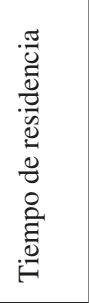 & 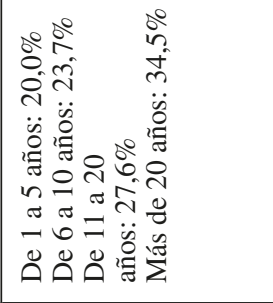 & 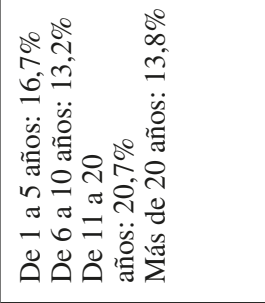 & 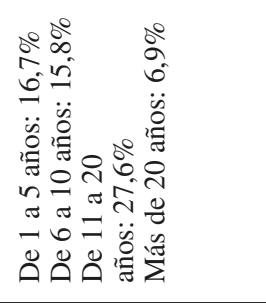 & 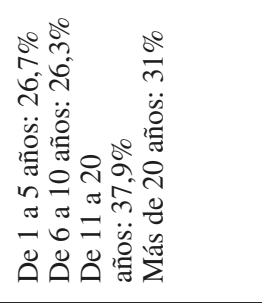 \\
\hline 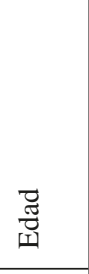 & 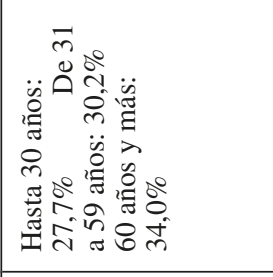 & 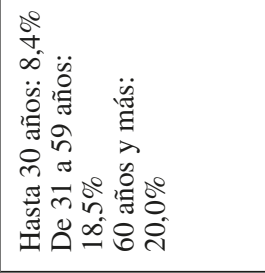 & 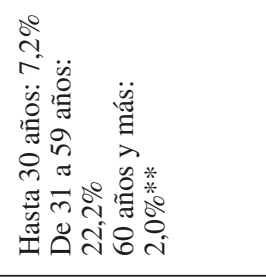 & 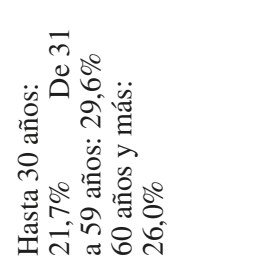 \\
\hline 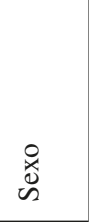 & 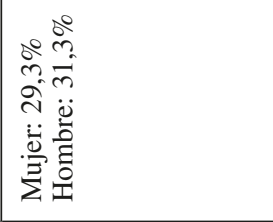 & 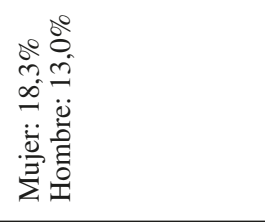 & 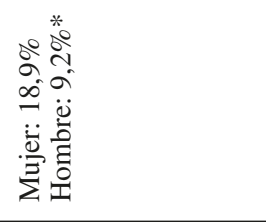 & 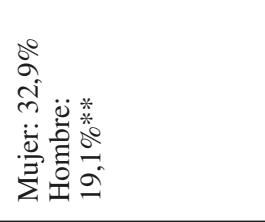 \\
\hline & 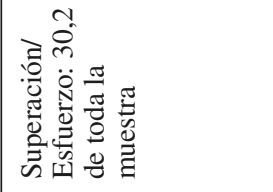 & 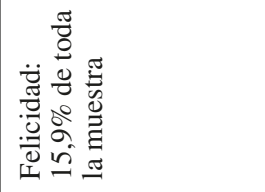 & 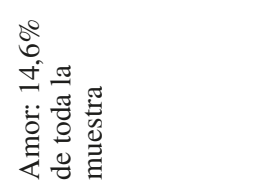 & 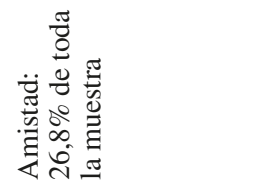 \\
\hline
\end{tabular}




\begin{tabular}{|c|c|c|c|}
\hline 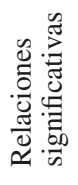 & 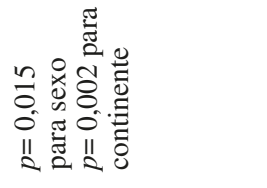 & 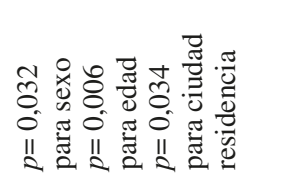 & \\
\hline 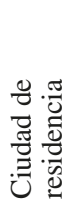 & 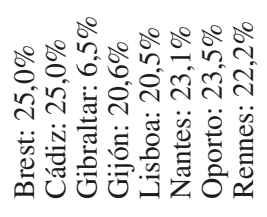 & 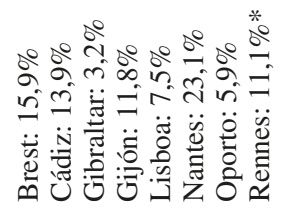 & 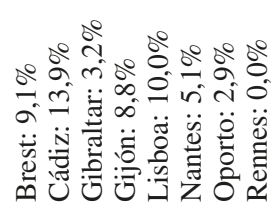 \\
\hline 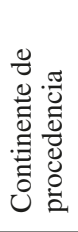 & 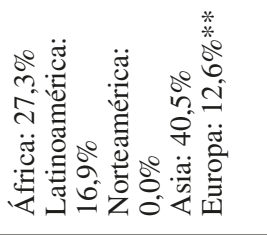 & 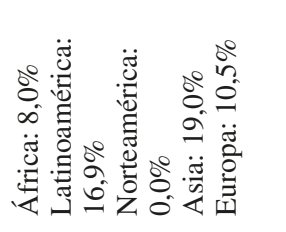 & 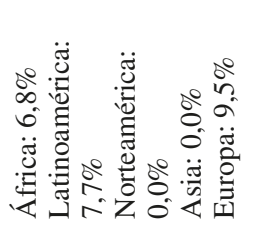 \\
\hline 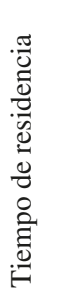 & 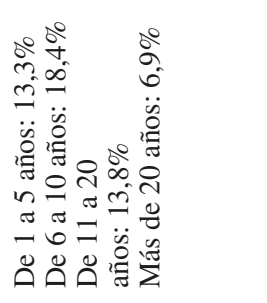 & 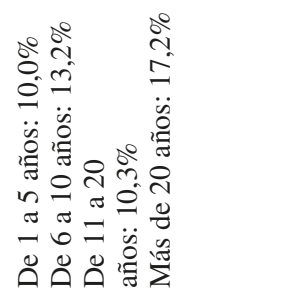 & 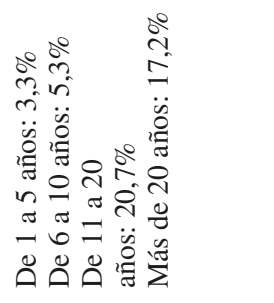 \\
\hline $\begin{array}{l}\overrightarrow{\widetilde{I}} \\
\text { I }\end{array}$ & 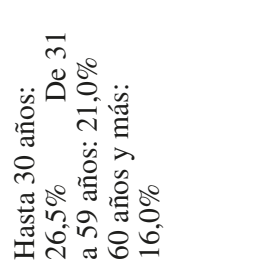 & 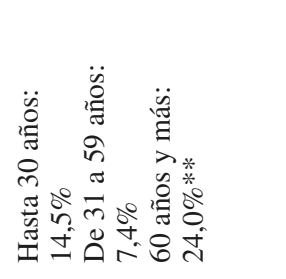 & 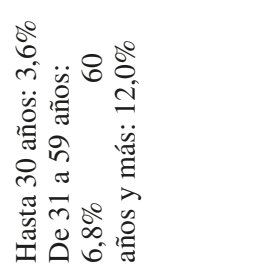 \\
\hline \multirow[t]{2}{*}{ 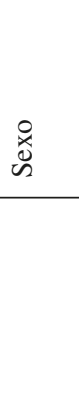 } & 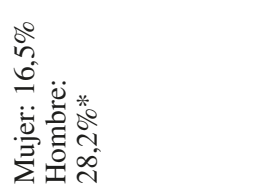 & 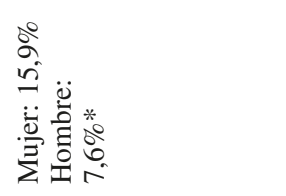 & 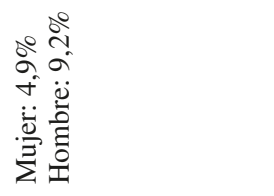 \\
\hline & 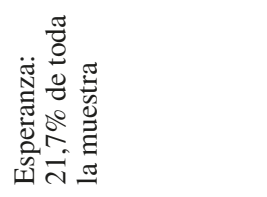 & 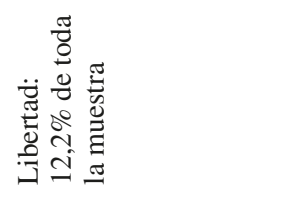 & 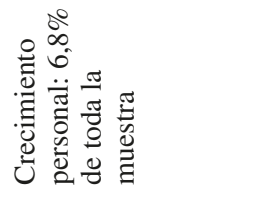 \\
\hline
\end{tabular}




\begin{tabular}{|c|c|c|}
\hline 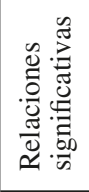 & 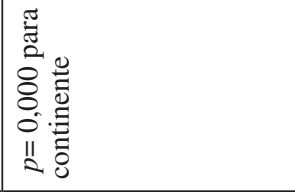 & 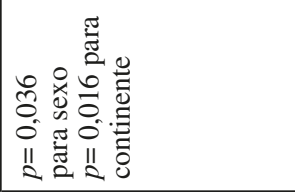 \\
\hline 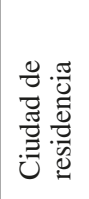 & 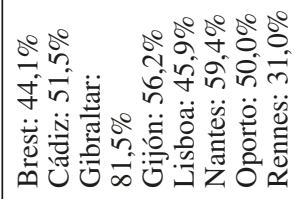 & 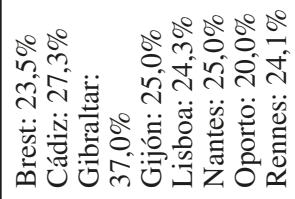 \\
\hline 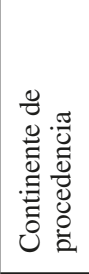 & 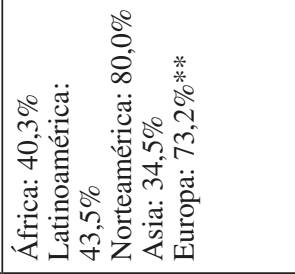 & 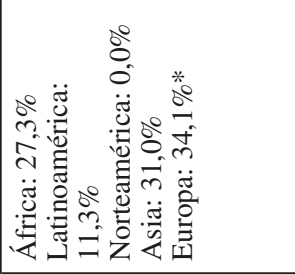 \\
\hline 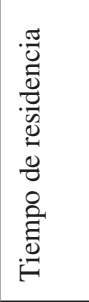 & 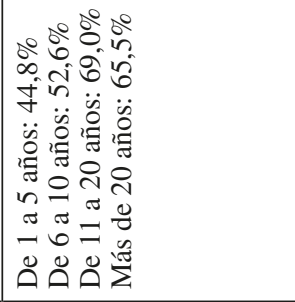 & 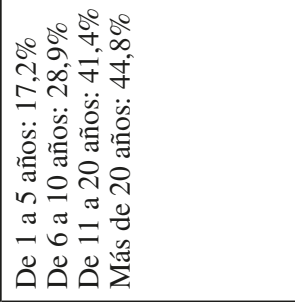 \\
\hline $\begin{array}{l}\overrightarrow{\tilde{J}} \\
\text { I }\end{array}$ & 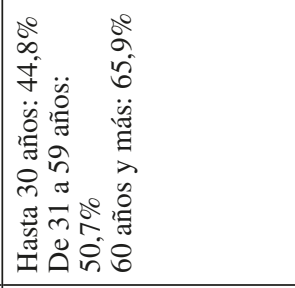 & 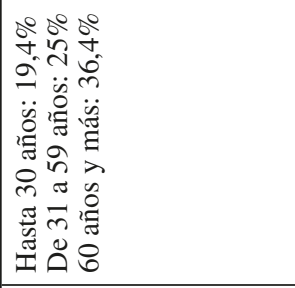 \\
\hline 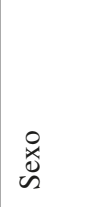 & 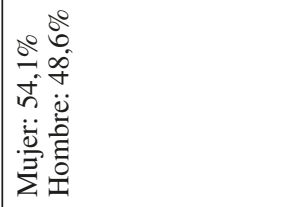 & 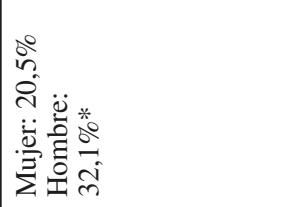 \\
\hline & 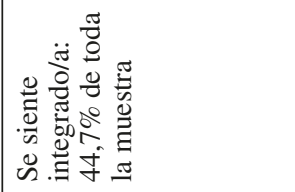 & 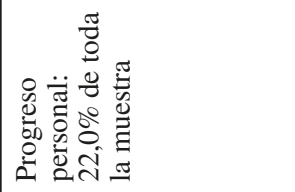 \\
\hline
\end{tabular}




\section{EL ANÁLISIS DE LAS CARTAS: LA INMIGRACIÓN COMO FENÓMENO AMBIVALENTE}

\subsection{Los aspectos negativos de la migración}

\subsection{1. $\quad$ El Miedo}

El miedo a lo desconocido está presente en muchos de los testimonios. Por ejemplo, en Lisa, originaria de Chad y residente en Rennes: "Cada día vivir con el miedo y la angustia, porque verse en una situación irregular no es fácil. Todo tenemos que hacerlo con cuidado, porque al más mínimo fallo nos pueden pedir la identificación..." [I212] $]^{4}$. En algunos testimonios aparece el temor a ser juzgado por haberse ido del país y por abandonar a los suyos. Es el caso de Arlete, angoleña, que se dirige a su madre: "No me juzgues por haberte abandonado. Debes saber que la decisión de dejar atrás mis estudios, el trabajo, los amigos y mis pacientes como ortopedista no fue fácil (...) escogí la libertad de marcharme y de conservarte en mi interior" [138]. Arlete huye de la guerra, pero el pensamiento de haber abandonado a su madre en Angola siempre permanece. Douce, congoleña residente en Nantes, manifiesta algo similar: "Llevo más de diez años sin una sola foto tuya que me permita aferrarme a tus facciones", refiriéndose a su padre [185]. Cristina, nacida en Manila y residente en Gibraltar, se enteró tarde del fallecimiento de su madre y solo le queda dirigirse a ella, diciéndole: "Ya hace 10 años desde la última vez que te tuve a mi lado. Te echo de menos y siento no poder volver a sentir tus brazos; ahora sólo siento un frío profundo" [I75].

\subsubsection{El dolor}

Está también en las cartas el hondo dolor de no haber podido estar con la persona que se ha querido. Por ejemplo, en Sha Alam, nacido en Bangladés y residente en Oporto, quien le confiesa a su madre que "Siento gran dolor por el momento en que padre falleció por no estar junto a él, un gran dolor que no consigo explicar (...)" [I256]. El intenso dolor está asimismo presente en Marie, congoleña residente en Rennes, quien le escribe a su difunta madre sin poder superar el desconsuelo de no haber estado en los últimos momentos: "Cuando llamé para anunciar mi llegada, me informaron de que habías muerto (...), llegaba demasiado tarde y ya solo podía visitar tu tumba. Pregunté si habías dicho algunas palabras para mí, pero no me dejaste ningún mensaje (...). Nunca me lo perdonaré" [I244].

\footnotetext{
${ }^{4}$ A los testimonios se les asignó un código que consta de la letra "I" mayúscula (Individuo) y un número, que designa el lugar que ocupa dicho individuo en el orden en el que aparecen las cartas (y fotografías) en la Enciclopedia. El orden de aparición en la Enciclopedia es estrictamente alfabético.
} 


\subsubsection{La tristeza}

La tristeza también se expresa entre los migrantes. Hasmik, una madre armenia ahora en Rennes, le escribe a su pequeña: "Sé que llegará el día en que estemos juntos. Hacemos todo lo que hace falta para que te reúnas con nosotros (...). Cada vez que hablo con tu padre por la noche de ti, se pone tan triste que se echa a llorar" [I137]. Cercano a la tristeza está el sentimiento de nostalgia por los seres queridos y por cosas contingentes. Al respecto, Héba, una egipcia residente en Rennes, escribe que "Si supieras lo que te echo de menos... Cuántas veces sueño con acurrucarme contra tu pecho, sintiéndome segura, con impregnarme de tu perfume como cuando era pequeñita... ¡Mamá, te echo de menos!" [I140]. También Irma, georgiana que vive en Rennes, le dice a su madre: "Me gustaría poder pasarme la vida hablando contigo, eternamente" [I157]. La nostalgia por otros aspectos se evidencian igualmente. Es el caso de Galina, una rusa residente en Nantes, quien le dice a su madre que es muy feliz, pero que echa mucho de menos la nieve [I124]. Homoud, por su parte, keniata residente en Lisboa, lo que más echa de menos es "(...) mi cultura; en África estamos en grupo desde la mañana hasta la noche, mientras que aquí estamos solos" [I146] (sobre esta soledad, volveremos inmediatamente).

\subsubsection{La humillación}

En ocasiones, la nostalgia se intensifica con la desilusión con Europa. Así ocurre con este lamento de Cheikh, un senegalés residente en Cádiz: "Pienso mucho en el trabajo que dejé para conseguir uno mejor y en que aquí va a ser muy complicado encontrarlo. Cuando mis tíos en Senegal me hablaban de la dificultad que hay en Europa yo no les creía (...)" [I61]. En el mismo sentido, también Liton le comunica a un amigo su desilusión como inmigrante que dejó Bangladés para trasladarse a Francia: "A decir verdad, cuando llegué a Europa, ésta no era lo que yo pensaba. Para sobrevivir en esta vida de máquinas, yo también tuve que ser una máquina" [I213]. Es la misma sensación que se recoge en el documental "El tren de la memoria" (00:15:07), "la primera sensación de ser diferente", o "la humillación de llegar en un tren y ser tratados como ganado" (ídem, 00:16:20).

De manera parecida Ibrahim, nacido en Mali y residente en Rennes, le escribe a su hija que, "Cuando estamos en África, estamos engañados con respecto a cómo es la vida en Francia. Aquí, la mayoría de los inmigrantes viven en la miseria social. En este momento, una gran parte de la sociedad nos rechaza a causa de los atentados terroristas que han golpeado a Francia" [I151].

Benson, un perseguido político procedente de Nigeria y residente en Nantes, le pone unas letras a su hijo recién nacido: "Un día, en un autobús, una mujer me pisó el pie. No pidió perdón. Se puso a chillarme y no podía responderle porque no hablaba francés. Todos en el autobús me miraban. Bajé y me eché a llorar (...)" [I44]. Elizângela, que es brasileña y reside en Lisboa, manifiesta que "(...) 
llegamos hasta a ser HUMILLADOS 5 por algunos portugueses, piensan que los brasileños son perezosos y que las mujeres solo vienen a prostituirse" [197]. Enver, turco residente hace 42 años en Francia, le describe a su amigo que "Nos ganábamos bien la vida $\mathrm{y}$, a partir de que llegamos al nivel económico de los franceses, empezaron a vernos con otros ojos. Descubrimos el racismo" [199]. El mismo Enver apunta la paradoja de que, cuando arribaron a Rennes en 1974, los jefes y encargados "Hacían todo lo que podían para que nos quedáramos en Francia y en su empresa; entonces, sin embargo, queríamos volver a nuestro país, pero el jefe nos proponía que trajéramos a nuestra familia a Rennes para instalarnos allí". Giliardo, oriundo de Cabo Verde y actualmente en Lisboa, le relata a su madre cómo siente dolor "cada vez que es escrutado por las mujeres que esconden sus bolsos cuando sube al autobús" [I128]. Kalil, estudiante universitario guineano en Nantes, expresa con amargura las situaciones de desprecio que vive: "La gente piensa que no eres más que un parásito, un ladrón... Se ríen de tu acento, te repiten que es imposible entenderte... Haga lo que haga, no me toman en consideración. Una de las cosas que más me entristece, es que, cuando tenemos que hacer grupos para un trabajo, nadie quiere trabajar conmigo, y si yo propongo unirme a ellos, fingen que ya tienen compañero para el trabajo" [I188].

\subsubsection{El desarraigo}

No es extraño que, en estas circunstancias, algunos de los migrantes sientan desarraigo, un sentimiento complejo que no está solo vinculado al racismo o a la desilusión del destino sino también a la nostalgia. En este sentido, Faustino, de Guinea-Bissau y ahora en Lisboa, constituye un contrapunto de la integración. Pobre y enfermo le confiesa a su esposa que "Cuando vine a Portugal, estaba enfermo; logré que me trataran y mejoré. Mi vida en esta tierra ha sido muy difícil. ¿Cómo voy a vivir en este país, enfermo e inmigrante?, no merece la pena" [I109]. Enver [I99], jubilado residente en Rennes, se lamenta del desarraigo que han sufrido sus hijos y sus nietos: "Aquí los jóvenes turcos no hablan muy bien turco, han olvidado su cultura, el respeto a los padres, la vida familiar... Se han mezclado con la cultura francesa, que tampoco dominan. Hemos ganado, pero hemos perdido". Obsérvese que, cuando habla de los nietos nacidos en Francia, se refiere a ellos como "los jóvenes turcos", no como franceses. Enver, que lleva toda la vida en Francia, nunca se sintió completamente integrado. Filomena dejó Angola de niña como consecuencia de la guerra civil, tras la declaración de independencia. Ahora reside en Lisboa y recuerda que " $\mathrm{Al}$ final, fuimos obligados a salir de nuestro país, a separarnos de nuestros amigos y de la familia. Y a partir de ese día, no sabíamos que la palabra 'migrante' iba a introducirse en nosotros como si fuera un sello ipara siempre! (...) $;$ he de morir migrante en mi propio país de nacionalidad, Portugal!" [I116]. Giuseppe, argentino vecino de Cádiz desde hace 40 años, le escribe, lúcido y desolado, a su hermana: "Cuarenta años

\footnotetext{
${ }^{5}$ Las mayúsculas aparecen en la carta original.
} 
fuera de mi país, que ya no es mi país. Y no te creas que siento que España lo sea (...), siento que no soy de ninguna parte (...)" [I130].

\subsubsection{La soledad}

La soledad aparece como una emoción que acompaña a la nostalgia, al desarraigo y a la humillación, sin olvidar que es compañera del miedo, del dolor y de la tristeza. Así, para Chiara, que está en Oporto procedente de Brasil, la soledad forma parte de su vida: "Paso mucho tiempo sola, que no es que no me guste, pero llega a ser excesivo. Aquí es más difícil hacer amistades. La gente es educada, pero no es simpática, no es cálida; es distante, fría, parece que no le gusta involucrarse" [I64]. También Dong manifiesta algo parecido: "Ante esta soledad, deseé, una vez, volver a Vietnam para estrechar a mi madre entre mis brazos. Sin embargo, comprendí que a mi madre no le alegraría, ya que mi familia había sacrificado mucho para que pudiera abandonar el país" [I83].

\subsection{Los aspectos positivos de la migración}

\subsubsection{El arraigo}

Contrariamente a lo que acaba de verse, otros testimonios afirman la hospitalidad de la tierra de acogida. Es lo que le sucede a Filipe, brasileño afincado en Lisboa, quien comenta a sus familiares que "No he sufrido discriminación de ningún tipo y no tengo nada de qué quejarme en cuanto a la hospitalidad portuguesa (...)" [I115]. De modo similar Hosna, residente en Lisboa y nacida en Bangladés, relata a su madre: "Nuestros vecinos nos respetan mucho y son una gran ayuda con el idioma y cuando tenemos que tratar asuntos burocráticos. Nos ayudan mucho especialmente con los niños. Los cuidan cuando lo necesitamos y nos dan buenos consejos sobre cómo los podemos educar y orientar, de acuerdo a este país" [I148].

La estonia Kaisa, que reside en Lisboa, le refiere a su padre las bondades de los portugueses: "cuidan más las unos de los otros. Se consagran a los demás, están más tiempos juntos. Hasta los desconocidos me ayudan muchísimo. Solo espero que un día tenga fuerzas para ayudar a los demás de la misma forma" [I187]. De un modo similar, el georgiano Irakli les dice a sus padres que "Los franceses me han ayudado muchísimo. Han conseguido devolverme mi vida, algo que era imposible en mi país. (...). Creo que el mundo debería tomarlos como ejemplo" [I156]. Luisa, una octogenaria española que volvió a España después de emigrar a Bélgica, le escribe a una amiga agradeciéndole la ayuda prestada: "Fue una decisión llena de incertidumbre, pero salió bien. Sobre todo, gracias a personas como usted. Ustedes reconocieron y valoraron el esfuerzo, el trabajo diario de miles de españoles que hicieron progresar a su país" [I219]. 
Incluso algunos migrantes atestiguan estar muy integrados y, en este sentido, el amor y una familia creada en el país de llegada aparecen como factores importantes: "Aquí también estoy en casa. Et j'aime ce pays aussi. Pays de mon amour, de mes enfants, des projets et des amis de la vie adulte" [I58], expresa Catrin, nacida en Gales y residente en Nantes. Evelize, por su parte, le confiesa a su prima que "Me gusta mucho vivir en Portugal, lugar donde he construido mi maravillosa familia (...), aquí en Portugal, es donde tengo todo lo que he ido construyendo a lo largo de estos años" [I102]. También las oportunidades y las ventajas del país de acogida son decisivas para sentirse plenamente integrado. Dagmara, polaca residente en Brest, le dice a su madre algo parecido: "Yo he encontrado aquí mi lugar de vida, mi embarcadero. En estos momentos es mi puerto (...)" [I76]. Lo mismo expresa Chava, colombiana residente en Nantes: "Francia es un país que te recibe con los brazos abiertos" [I60], y Cristiane, brasileña residente en Brest: "Mi vida ha cambiado mucho desde que vine aquí $\mathrm{y}$, hoy por hoy, no tengo previsto volver. Brasil permanecerá siempre en mi corazón, pero ahora hay sitio además para Francia, que tan bien me ha acogido" [I73]. Por su parte, Fouzia, vecina de Oporto y originaria de Marruecos, le dice a una amiga que "Aquí nunca me he sentido inferior, ni he sentido el racismo" [I118] y Mikhail, egipcio residente en Gibraltar desde hace más de 40 años, escribe sobre esta ciudad que es "Un lugar donde poder pasar el resto de mi vida, encontrar la paz, lejos de tensiones raciales y de la guerra. Un lugar donde musulmanes, judíos, negros y blancos se tratan con dignidad como seres humanos" [I263]. Héba [I140] manifiesta que "Siempre me quedarán raíces profundas allá, pero se han entrelazado con otras nuevas y se han arraigado profundamente en mi segunda patria". Situación similar explica Hedia, tunecina residente en Nantes desde hace más de 35 años: "Ya sabes que para mí venir a Francia fue una suerte. Pude ampliar mis horizontes y he ido echando raíces aquí y la vida me sonríe, aun cuando no todo es de color de rosa" [I141].

\subsubsection{Sentirse libres}

El arraigo se vincula con la libertad, no sólo para aquellos que huyen de una situación de conflicto armado, sino también como un crecimiento personal. La argelina Dihia le explica a su madre lo seguro que es vivir en Brest: “(...) me gusta esta ciudad, su tranquilidad, se puede salir a pasear incluso por la noche sin que nadie te moleste..." [I82]. Doruntina, una muchacha kosovar residente en Brest, le dice a su amigo que "Ahora me siento muy bien, voy a vivir en una sociedad donde no hay diferencias entre hombres y mujeres" [I84]. La experiencia de la libertad está, igualmente, muy presente en la carta que Fariborz, iraní exiliada en Nantes, le envía a su hermana: "En Francia, tuve la suerte de conocer otra sociedad, donde reinan la libertad, la igualdad y los derechos humanos. Me abrió los ojos. Vi las diferencias entre dos sociedades y dos culturas y pude compararlas (...). Tú, tus hijos y tu marido debéis buscar cobijo en la luz, en la modernidad" [I103]. Fátima, tunecina residente en Nantes, se dirige a su madre: 
"Te diré que aquí soy feliz, vivo, las mujeres tienen derechos, somos libres para pensar lo que queramos y para decirlo" [I105]. La conciencia de la libertad hace que se rechacen ciertas costumbres por ser contrarias a la libertad personal, y dejan paso a un sentimiento contradictorio entre el amor y el reproche. Es el caso de Héba [I140], cuando escribe a su madre: "Mamá, eres lo más valioso que tengo en esta vida", para, a continuación, interrogarle: "Y tú, mamá, ¿también quisiste castigarme al decidir mi ablación? ¿O es que querías protegerme? No quiero que me des una respuesta, ni tampoco que estés triste. Sé que lo único que hiciste fue reproducir lo que te habían infligido a ti misma, al igual que a todas las otras madres de tu época". Para Khaddouma, argelina, Francia le permitió separarse de su exmarido tras una vida llena de maltrato, habiendo pasado por un matrimonio forzado: "Nos pegaba a todos con una zapatilla de goma. Hubiera preferido la muerte, aborrecía la vida" [I196]. Salir de Venezuela fue para Marco Antonio algo liberador, así se lo explica a su padre, desde Cádiz: "A pesar de que dejaba todo a miles de kilómetros, fue un adiós liberador: dejé el infierno para caer en el paraíso." [I231].

\subsubsection{El crecimiento personal}

Para algunos migrantes la experiencia ha supuesto un crecimiento personal. Es lo que le sucede a Casimiro, que vive en Oporto procedente de Guinea-Bissau: "Llegué y dos días después conseguí trabajo. Llegué a jefe de equipo y más tarde a responsable de la recepción de equipamiento hospitalario" [I55]. El viaje migratorio también es percibido como una oportunidad vital para conocer otras culturas, como le ocurre a Diana, venezolana que se encuentra en Gijón: "Me he dado cuenta de que he tenido la oportunidad de vivir experiencias muy enriquecedoras y he podido conocer a personas extraordinarias, ha contribuido a mi crecimiento personal" [I81]. También señala algo parecido el alemán Harry, que vive en Brest y que le resume a su amigo: "Introducirse en una cultura, descubrir una forma de vivir distinta nunca es fácil, pero siempre es enriquecedor (...)" [I136]. El tunecino Hosny, por su parte, confiesa a su padre que "Amo Brest apasionadamente, que también me ama y me ha dado tanto (condiciones para el éxito, asociadas con unos valores preciosos como la seriedad, el respeto, el trabajo, la integración) y es este contexto el que ha favorecido mi florecimiento" [I149]. Otro testimonio de crecimiento lo ofrece Helena, alemana residente en Lisboa: "He descubierto la lentitud, la espera, la paciencia (...) al final, todo acaba por funcionar e ir bien. Y siempre funciona con una sonrisa. Y le he cogido el gusto al sonido de la lengua portuguesa" [I142]. Juan, argentino residente en Brest, le escribe a su amigo: "A mí me gusta la cultura bretona (...) A mí la Bretaña no me adoptó, yo adopté a la Bretaña" [I179]. La radicalidad del conocimiento de otras culturas lleva a Martine, belga que reside ahora en Cádiz, a ser muy severa con la sociedad belga: "El regreso a Bélgica fue brutal: el asco del consumismo excesivo, el aspecto de las costumbres burguesas, la abrumadora sensación de soledad en una sociedad cerrada en su grisura" [I250]. Maurice, irlandés afinca- 
do en Cádiz, escribe bellamente que "Siempre me ha gustado pensar que nuestro hogar es aquel en el que nuestros pies corren más libres, y he sentido el placer de itinerar por el mundo" [I254]. Destaca también la experiencia de John, inglés residente en Gijón, que, cuando le preguntan si por Navidad va a casa, él contesta que ya está en casa y que "Cuando vuelvo [a Liverpool], cada vez más me parece un país extranjero" [I172].

\subsection{Análisis Iconológico de las fotografías: imágenes del imaginario de los inmigrantes}

Antes de efectuar el análisis iconológico de las fotografías, recordemos que éstas han sido realizadas por los artistas siguiendo las instrucciones de los migrantes, pero en un diálogo con el lenguaje fotográfico: el lugar donde se retratan, cómo posan, los gestos o expresiones, la vestimenta, con qué objetos se vinculan y con qué personas aparecen, la luz, el encuadre, los picados o contrapicados, el primer plano.... Además, los/as fotografiados/as son los mismos que han escrito las cartas y, por tanto, desean mostrar sus sensaciones y sus emociones no sólo con los textos sino con sus retratos. Por eso, las fotografías son, simultáneamente, imágenes construidas por el fotógrafo y del imaginario de los migrantes, en tanto que constituyen un testimonio situado a mitad de camino entre el arte y el documental, entre la intención del artista y la realidad que aquellos perciben y el universo imaginativo que generan sus intensas impresiones y pensamientos; en todo caso, la habilidad de los fotógrafos logra congelar las sensaciones y las emociones de los migrantes ante las experiencias que están viviendo, así como el modo en el que sus cuerpos reaccionan ante ellas.

Por eso, el análisis de estas fotografías desvela la presencia de una serie de repeticiones que permiten hacer una clasificación de los temas que (re)presentan aquello que más preocupa o interesa a sus protagonistas. En primer lugar, están los lugares en los que son retratados y, derivado de ello, el apego/desapego a los mismos. En este sentido, destacan las fotografías realizadas en los lugares de trabajo o de estudio; las de las calles, plazas o parques públicos; las que muestran el hogar o la casa donde viven y cómo se sienten en su interior; y, finalmente, las que presentan a los actores sociales ante el mar o el océano como el espacio puente entre su origen y su destino. En segundo lugar, las imágenes manifiestan el estado de ánimo de la persona retratada: la seriedad extrema, la tristeza profunda o la alegría contenida o desbordada. En tercer lugar, están las miradas de los migrantes, interpelándonos o ajenos a nosotros y, sobre todo, mirando para otro lado, distinto al del camino que hacen y al del lugar, hogar o trabajo donde se encuentran. Finalmente, la gran mayoría de fotografías nos presenta a los retratados sin compañía, con alguna pequeña excepción en que aparecen con su pareja o familia. 


\subsection{El apego o desapego a los lugares}

\subsubsection{Calles y plazas que expresan emociones}

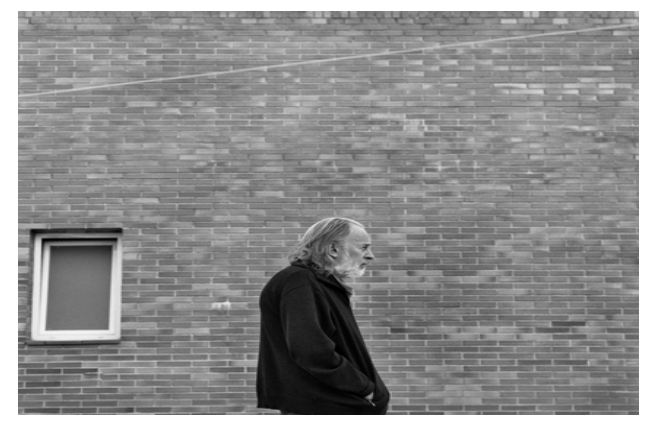

Giuseppe [I130], un hombre maduro y canoso, camina por la calle, por delante de la pared de un edificio de ladrillo que solo tiene una ventana pequeña, cerrada. Además, lo vemos de perfil, ajeno a nosotros o al edificio, y su mirada pensativa se dirige hacia adelante, hacia lo que está por venir, pero sin convicción, como si fuera arrastrado, tal y como denota su lento caminar. Su espalda está ligeramente encorvada, probablemente como resultado de los numerosos pesos -físicos y psicológicos- soportados, mientras que sus manos se muestran metidas en los bolsillos, inactivas y ocultas por el frío. ¿De dónde viene Giuseppe?, ¿hacia dónde va?, congelada su imagen frente a una pared de múltiples y fragmentados ladrillos que es mucho más alta que él, que lo limitan, y ¿que lo encierran?, sin apenas posibilidad de entrar, o de ver, dentro o fuera, lo que sucede. No extrañe que ande cansado y que la cabeza esté ligeramente abatida, como si soportara las múltiples fracturas, penalidades y faenas sufridas. Sin olvidar que, al contrastar el artista la fotografía en blanco y negro, la chaqueta oscura con el gris del edificio y el blanco de la ventana y, por consiguiente, al resaltar la ausencia de color, ha dado el tono melancólico de "un paria que trata de vivir allí donde cae", de un caminante, de un desarraigado ${ }^{6}$.

${ }^{6}$ A partir de aquí, cada vez que colocamos una frase entrecomillada se refiere a un fragmento de la carta escrita por estos migrantes a sus conocidos o familiares y que complementa o contrasta con la imagen fotográfica, enriqueciéndola en su significado. En este caso, Giuseppe ha escrito en su carta que "siento que no soy de ninguna parte". 


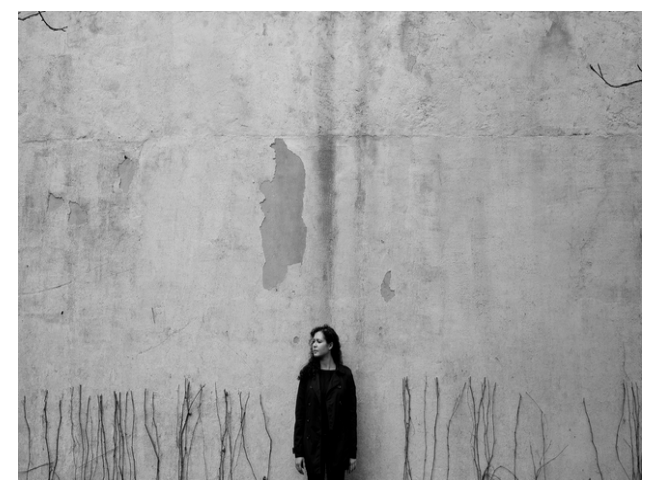

Diana [I81] está también de pie, delante y pegada a una pared muy alta, desconchada, metáfora del paso del tiempo y de las heridas sufridas. Esta pared es de color gris o blanco, lo que contrasta con la vestimenta y el pelo negro de ella. Además, una serie de plantas enredaderas se le adhieren verticalmente, pero sin hojas, como si estuvieran secas o como si aún no fuera la estación en la que rebrotan. Diana gira la cabeza con convicción sobre su cuerpo erguido, por lo que su cuello está tenso, de manera que su visión es lateral y no central. Por tanto, la suya es una mirada enérgica, activa, que busca otro emplazamiento, otro lugar, y quizás anhela, con él, una futura renovación personal ${ }^{7}$.

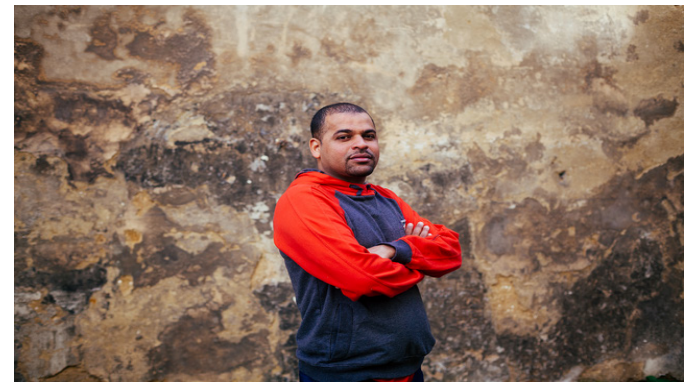

También Homoud [I146] está de pie, pegado a una pared, desconchada, envejecida y con diferentes tonos de marrón, metáfora tal vez de su tierra originaria. Sin embargo, él está solo en la imagen y los colores del chandal que porta chocan, por su occidentalidad, con los terrosos que tiene detrás, expresando de este modo su profunda soledad y la nostalgia que tiene de la vida colectiva que desarrollaba $^{8}$ en su terruño, la África a la que echa profundamente de menos. No obstante, su mirada, dulce y directa hacia nosotros, sin resentimiento, su ceja

7 "Cada vez que recuerdo las experiencias vividas en estos dieciocho años, se incrementan las ganas de seguir viviendo en diferentes países y tener la oportunidad de seguir aprendiendo".

${ }^{8} \mathrm{El}$ anhelo de Homoud por África y la vida que allí lleva lo expresa indicando que allí "estamos en grupo desde la mañana hasta la noche, mientras que aquí estamos solos". 
arqueada y los brazos cruzados sobre su pecho, cerca del corazón, logran trasladarnos, con emoción, su "esperanza de que todo salga bien".

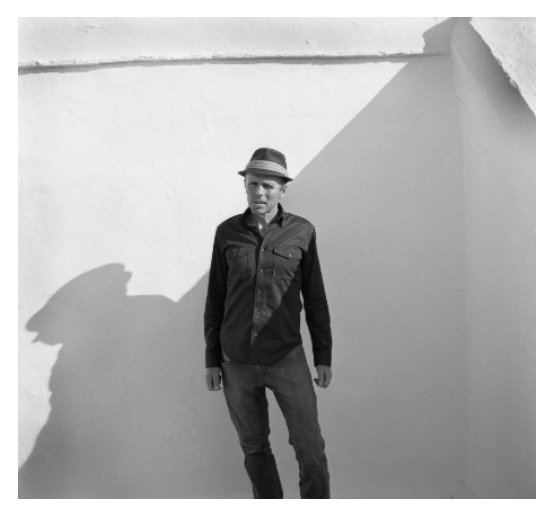

Maurice [I254] ha sido fotografiado ante dos sobrias paredes encaladas, parado en medio de ellas y como si lo rodearan, lo recogieran o lo protegieran, no en balde él vive ahora en la Granada de casitas blancas donde se encuentra feliz, como él mismo declara ${ }^{9}$. Sobre la mitad de esa pared -signo probable de lo que dice el protagonista en su carta, que "llevo viviendo aquí la mitad de mi vida"se extiende, por ella misma y por su cuerpo, una suave penumbra, en diagonal, de la que emerge -como en el cine expresionista- una inquietante sombra que, en contraste con la estática figura real, parece caminar y que, significativamente, se dispone en una dirección contraria. De este modo, el fotógrafo traslada al lenguaje visual la desazón de Maurice en estos momentos existenciales ${ }^{10}$. No extrañe que tenga los ojos medio cegados por la luz del sol, aunque porta sombrero, y que su cuerpo esté ligeramente arqueado, como escudriñando el sol y al mismo tiempo sumiéndose en la semisombra, dudando entre buscar la luz o la oscuridad, moverse o quedarse quieto, ir al lugar del que procede o permanecer en el que ahora vive.

9 "Se vive muy bien aquî"

10 "De repente se apodera de mí una desazón extraña como cuando un gato se eriza al perseguir una sombra en movimiento". 


\subsubsection{La alegría o tristeza del espacio de trabajo o estudio}

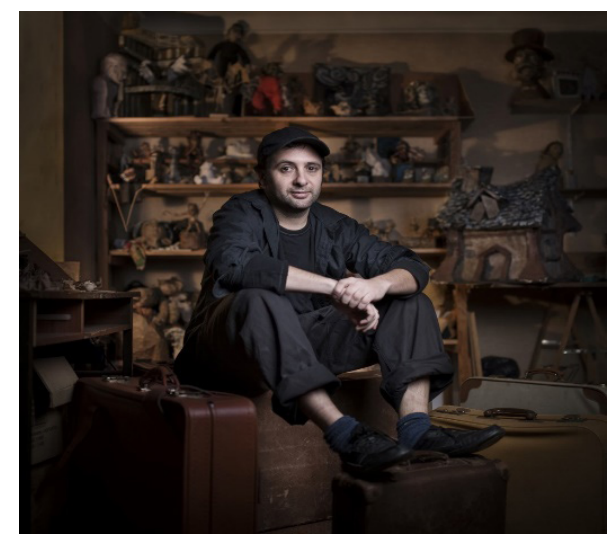

Juan [I179] está en una habitación donde aparecen, en estanterías, múltiples objetos entre los que destacan una serie de muñecos, tal vez confeccionados por él mismo, indicadores de su profesión. Está sentado, va vestido de negro con ropa cómoda, sencilla y austera y tiene los pantalones y las mangas arremangados; sus pies están encima de una maleta y otra, más grande, se encuentra a su lado. Su rostro, iluminado, deja ver unos ojos oscuros y serios y unos labios apretados, sin rabia, que anuncian una sonrisa. Ciertamente, está sentado, tiene trabajo, pero las maletas dispuestas para emprender un nuevo recorrido nos señalan que él es un "viajero", que él es lo que es y que viene de dónde viene. En efecto, en este preciso instante nada parece indicar que se halle en la Bretaña de su destino o en la Argentina de su origen, sino en un espacio-hogar de ficciones y sueños que denota lo que siempre ha sido: titiritero, contador de cuentos.

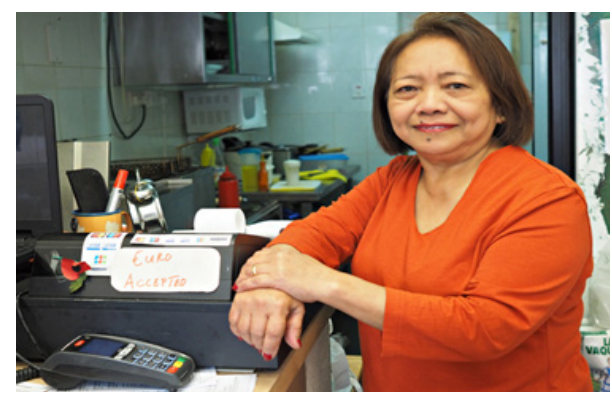

También Cristina [175] está en su lugar de trabajo, donde se aceptan euros. Lleva en su mano un anillo, ¿de casada? Sus ojos, de edad madura, han contemplado trabajos y pesares, y expresan un intenso dolor vivido ${ }^{11}$. Pero la imagen

${ }^{11}$ Tal y como señala en su carta. 
quiere destacar que, a pesar de todo, ella sonríe y viste con un jersey de color naranja y lleva las uñas y los labios pintados de rojo, el tono de la pasión y de la alegría de vivir.

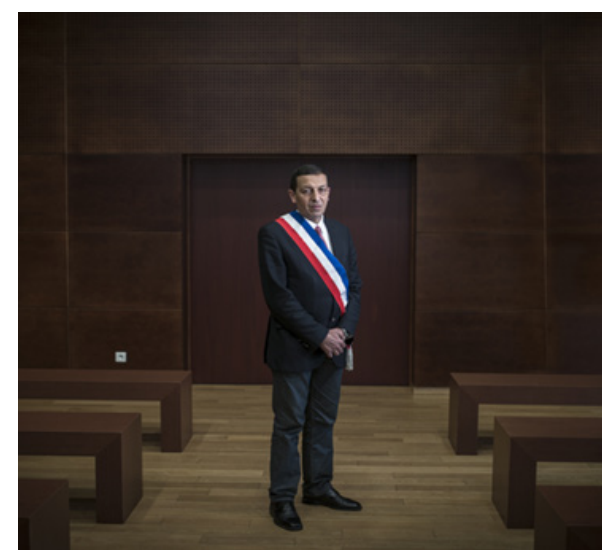

La expresión de Hosny [I149] es muy diferente. Está solo, de pie, en medio de una sala, en su centro, con los asientos vacíos, delante de una puerta cerrada, que lo enmarca como si fuera la fotografía de un dignatario colgada en la pared. Porta en su pecho una banda con los colores de Francia, y va bien vestido, con un traje oscuro y unos zapatos negros muy relucientes. Las manos están cruzadas debajo de su tórax y su pose general, así como el lugar central que ocupa en el espacio, desprenden seguridad en sí mismo. Además, su mirada es seria, de consciente responsabilidad, pues ha conseguido, con éxito ${ }^{12}$, ser un representante político en su país de destino ${ }^{13}$.

${ }^{12}$ Una palabra que repite varias veces en su carta.

13 "Me han elegido teniente de alcalde de Brest". 


\subsubsection{El mar, que une y separa}

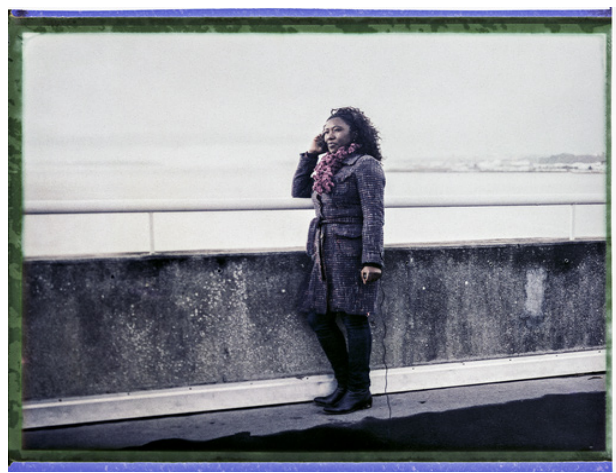

Arlete [138] está sola, muy pegada a un muro, como buscando en él seguridad, pero al mismo tiempo queriendo estar cerca del mar, algo brumoso, que se abre detrás. Está hablando por el móvil y su cuerpo está hierático, con el brazo izquierdo caído, mientras que su expresión es muy seria y concentrada: está comunicándose con alguien muy cercano y al tiempo lejano, al que no puede ni tocar ni abrazar. Para reforzar estas paradojas y emociones, es un día frío y eso la obliga a abrigarse mucho y, de este modo, a ocultar la incomodidad de su cuerpo incomunicado, si bien un pañuelo rojo desplegado sueltamente sobre el cuello y extendido generosamente hacia su pecho recuerda levemente que viene de otro clima $^{14}$, de otra intimidad, y manifiesta la nostalgia que la inunda ${ }^{15}$.

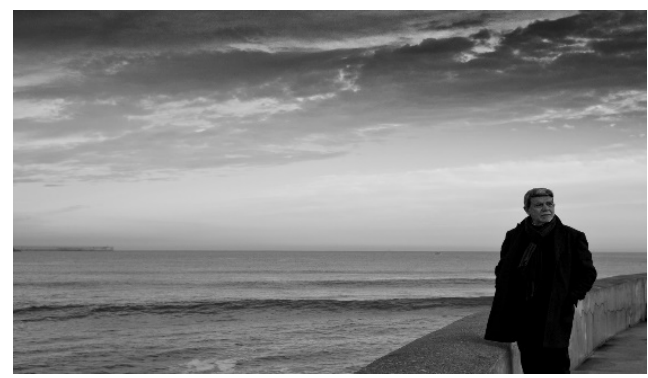

También José [I174] camina por la esquina de un paseo marítimo, muy pegado a un muro bajo que rodea las tranquilas aguas que se abren al infinito. Él, vestido con un abrigo negro que le protege su cuerpo y sus manos, ocultas, mira al lado contrario del mar, ¿hacia el lugar de su destino? Ahora bien, al estar muy ligado al muro y al agua, inmensas extensiones de su pequeño cuerpo, su mirada

14 "Aquí, las costumbres son diferentes, igual que la alimentación y el clima".

15 "Cuando la nostalgia me atenaza, me siento junto al mar. Contemplo su inmensidad, las olas y el sol, que se pone en el horizonte". 
denota la nostalgia que siente al recordar lo que ha dejado atrás, tras las calmadas aguas, a las que él llamaría su "territorio emocional" ${ }^{16}$. De él forma también parte el cielo con nubes, que nos sugiere ensoñaciones diversas, lo que se refuerza con el mechón blanco de su pelo que, a modo de nube, conecta su cabeza y el cielo, sus recuerdos y el presente, de dónde procede y dónde se encuentra.

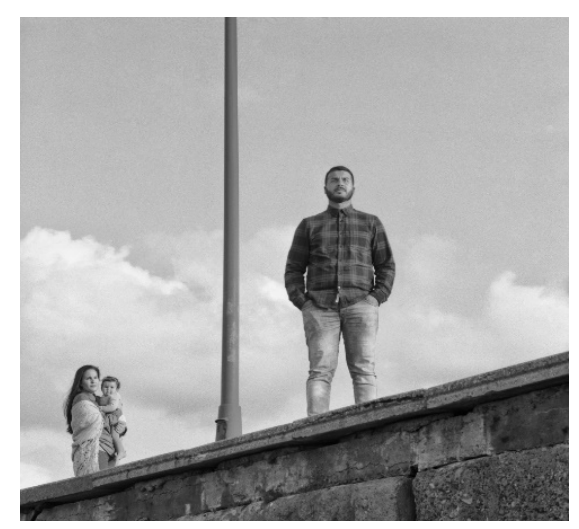

Marco [I231] aparece en esta fotografía en blanco y negro -como la anterioren un contrapicado, algo distanciado y separado por una farola de una mujer y de una niña, que está en sus brazos y que son su familia ${ }^{17}$. Todos miran hacia el mismo lugar y lo hacen seriamente, pero la de él es una observación de altura y dirigida hacia lontananza, lo que se refuerza por su ubicación en el borde y encima de un muro, que lo eleva. Dos arrugas paralelas encima de la nariz y entre los ojos indican que está concentrado en sus pensamientos, en sus recuerdos, mientras que sus brazos metidos en los bolsillos expresan -una vez más- una situación de espera, eso sí, tranquila, no desesperada. Sin embargo, el cielo tiene algunas nubes blancas que envuelven a la mujer y a su hija, pero no a la cabeza del hombre, lo que es posible que represente que él es consciente que el encuentro con los seres amados, motivo de su pensamiento, que están más allá del muro y del mar -que no atisbamos- nunca tendrá lugar ${ }^{18}$ y que la tranquila resignación es el último sentimiento que le queda al respecto.

16 "Las ciudades, los paisajes que vivimos están unidos a los sentimientos, a las emociones y los estados de ánimo que tenemos. Esto sucede porque siempre llevamos con nosotros un "territorio emocional"',. Sobre este concepto puede verse (Cassain, 2018: 311).

17 "Tengo la dicha de contar, a mi lado, con la mujer perfecta para mí... Ella me ha dado el regalo más bonito, el tesoro más preciado, mi pequeña, mi hija, tu nieta”.

18 "... aunque este papel no te va a llegar nunca". 


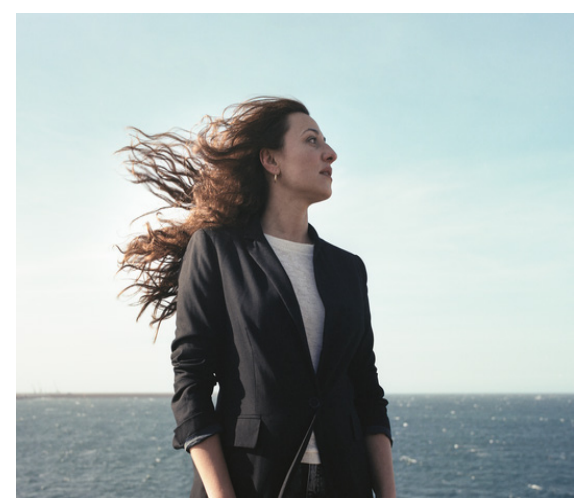

En un primer plano vemos a Gianina [I127], que está de pie, frente a un mar, suavemente picado y borroso, signo de su nostálgico estado de ánimo ${ }^{19}$, y un amplio cielo azul, más enorme que el propio océano, prolongación de un pensamiento que la lleva lejos. Además, tiene la cabeza ligeramente inclinada hacia arriba, los cabellos muy sueltos y la mirada hacia otro lado, atenta, con los ojos bien abiertos, las cejas arqueadas y los labios sensualmente entreabiertos, como si quisiera hablarle al paisaje de tú a tú, como si lo que tuviera que decirle fuera algo muy sentido e intenso. Por otra parte, lo que está más allá de este mar brumoso, levemente agitado y lejano, lo que se encuentra en la misma dirección que su cabello, no deja de constituir un electrizante recuerdo y un doloroso aguijón. Simultáneamente, la brisa marina que roza el rostro y las manos con las mangas alzadas y que ensortija el cabello denota, por el contrario, un más acá placentero y liberador. En suma, lo que Gianina desea comunicar es tan grande como un infinito cielo porque, en sus sentimientos, caben todos los matices de las contradicciones del alma humana, dolorida por la ausencia y, al tiempo, esperanzada por el deseo de libertad.

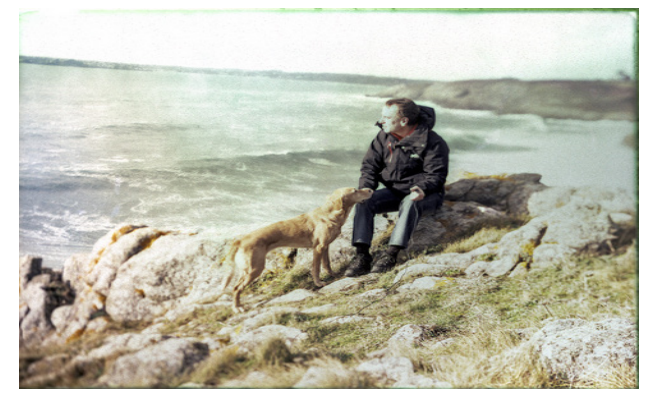

19 "Todos los días me acerco al mar, con los pasos cansados de tanto trabajar, me acerco a la orilla y me siento en la arena fina, oteando el horizonte lejano con los ojos y con la mente. Es el momento cuando me apareces en la imaginación, tú, mamá. Tu rostro se proyecta sobre el cielo claro y se refleja en el mar, revuelto, igual que mi alma". 
También Harry [I136] está al borde del mar. Acompañado solamente de su perro, que lo observa fielmente, está sentado pensativo sobre unas rocas en un paisaje solitario y al lado de unas olas algo movidas de tristes colores verdosos y grises. Pero él, a diferencia del resto de inmigrantes retratados, sí contempla ensimismado ${ }^{20}$ el mar y el sempiterno movimiento de sus olas, que cíclicamente van y vienen. Como tiene los labios entreabiertos, la mirada seria y el puño cerrado, parece querer decirle algo al piélago, pero con una cierta rabia o enfado ${ }^{21}$. Y es que ésta podría representar la elocuente imagen de un transterrado, de un "extranjero", que llega a una tierra baldía y que deja atrás un horizonte brioso y un tiempo en el que todo está detenido; pero también que ahora está en un sitio en el que nunca sucede nada nuevo, en el que jamás avanza su integración.

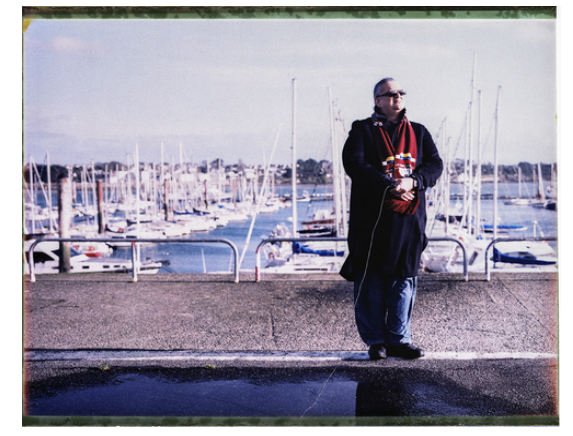

Georges [I126] se encuentra delante de un puerto deportivo con yates, a los que les da la espalda. Está de pie, con la misma posición vertical y digna que los mástiles de las embarcaciones, pero en el quicio de uno de los pantalanes, como -su pie adelantado así lo indica- si quisiera avanzar hacia el precipicio, hacia el agua, y entrar dentro de ella ${ }^{22}$. Lleva gafas de sol negras en un día frío y algo brumoso y una bufanda roja, de su equipo deportivo, que contrasta con su abrigo oscuro. Aunque no vemos sus ojos, su mirada, oscurecida por las gafas, es seria y, su cabeza, ligeramente inclinada hacia arriba, es ajena a lo que le rodea y, más bien, parece empujarle -como su bufanda- hacia el mar que tiene delante, hacia el abismo de su origen.

20 "La magia del océano siempre me impresionará, saborear la presencia de la naturaleza con todos mis sentidos me mantiene vivo y me ayuda a regenerarme y me da fuerza para seguir viviendo".

${ }^{21}$ A Harry, como escribe en su carta, no le gusta que continuamente le recuerden que él es alemán, cuando se siente plenamente integrado en Francia.

22 "Brest, situada al noroeste de Francia, está pegada al Atlántico, con hermosos paisajes marinos, que me recuerdan siempre a nuestras aventuras de buceo en nuestra amada isla de Margarita". 


\subsection{3. ¿Casa u Hogar?}

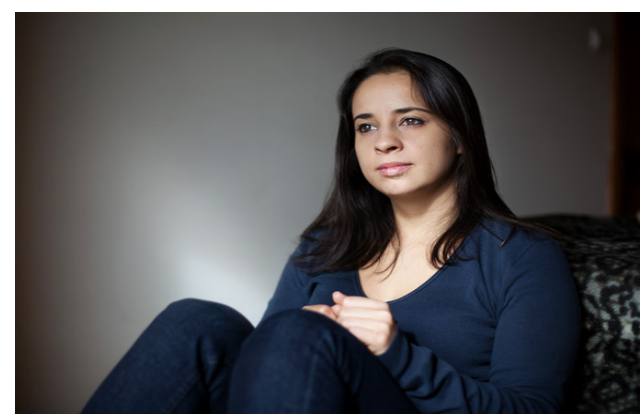

Chiara [I64] está sentada en un sofá situado en un espacio indefinido, con una pared vacía y tenuemente iluminada. Sus ojos y su pelo son de color negro y la ropa que viste es azul oscuro y, aunque sus ojos le brillan, su mirada es -como la habitación y la ropa- triste, apagada y profundamente melancólica, mientras que sus labios, ligeramente entreabiertos, expresan que algo quisiera decir, sin que encuentre las palabras adecuadas, sin que éstas logren salir de lo más profundo de su corazón. Su cuerpo no está expandido, sino recogido, cerrado ${ }^{23}$, sobre sí, mientras que sus manos, con los dedos plegados, se apoyan sobre sus rodillas, como si se protegiera en el interior tranquilo de una casa, diluida, sin nada personal, que no parece realmente su hogar ${ }^{24}$.

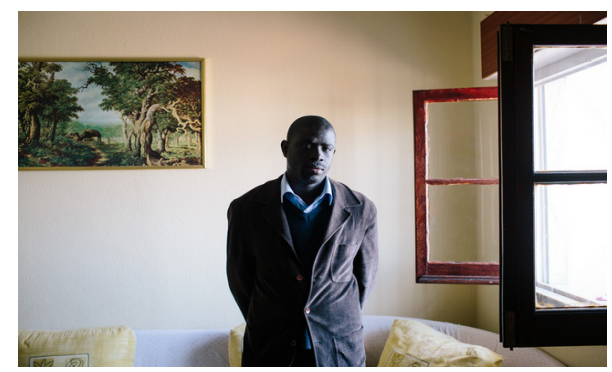

Faustino [I109] se halla en el salón de una casa de paredes claras y limpias, con las ventanas abiertas y no pintadas minuciosamente, que tiene un sofá y cojines y un cuadro con un árbol de un tronco retorcido y añoso. Está de pie, solo, en medio del salón, con las manos en la espalda, y observándonos. Su mirada es muy seria, si bien la mitad del rostro oscuro está en penumbra, como oculto -al igual que las manos-, sumergiendo en el misterio o en la negra tristeza una parte

23 "Soy una persona cerrada, eso forma parte de mi personalidad, pero aquí es más difícil todavía hacer amistades...".

24 "Discúlpame, mamá, pero he aprendido a que esto me guste...". 
de su vida, y tal vez la que ahora lleva ${ }^{25}$. Faustino viste de forma austera y sencilla, de trabajador, pero su ropa está limpia, y tiene dos botones de la chaqueta desabotonados. La estancia no está cerrada sino abierta, de par en par, a un exterior que no se ve, pero por el que entra la luz que ilumina la mitad de su rostro, como si lo que está más allá del interior del salón lo alumbrara y éste lo sumergiera en lo que actualmente está padeciendo ${ }^{26}$. Al tiempo, no vemos sus pies en el suelo y su cuerpo tampoco está plenamente cerrado por esa vestimenta que representa una determinada función social y un estatus actual; más bien, parece querer desnudarse o volver a su forma de vestir anterior. Sin embargo, a pesar de que todo presenta una dignidad asombrosa, nada hay acabado ni formalizado, ni la manera occidental de vestir ni el modo de entender el trabajo de aquí; solo parece sólido el árbol representado, que es ficticio y, en su exuberancia, de otro lugar. Además, sus raíces deben ser tan profundas como su añoso tronco, lo contrario a lo que le sucede en estos momentos a Faustino, cuyos pies no se muestran, expresando que siente que ya no tiene raíces ${ }^{27}$.

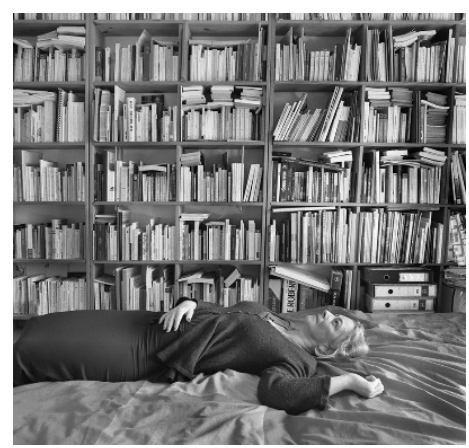

Martine [I250], una mujer rubia de mediana edad, está recostada sobre un sofá o cama, delante de una librería repleta de libros; en uno de ellos, se ve la palabra francesa "perdu". Mira, ensoñadoramente, hacia arriba con sus ojos muy abiertos, a la misma dirección vertical que los libros, como si éstos, contrastados con la horizontalidad de su cuerpo, representaran sus esperanzas o la posibilidad de crecimiento personal o de ascenso social. Así parecen indicarlo también sus labios prietos, su rictus congelado, y la posición echada y soñadora de su cuerpo. ¿Pero, qué está meditando?, ¿qué es lo que ha perdido?, ¿qué es lo que ha ganado?, ¿su tiempo, un amor, otro país, otra cultura?

25 "Cuando vine a Portugal, estaba enfermo; logré que me trataran y mejoré. Mi vida en esta tierra, sin embargo, en cuanto al dinero, a tener un sitio donde dormir, ha sido muy difícil. Ese es el motivo de mi pena, del gran dolor que siento en el corazón. Cómo voy a vivir en este país. Yo, enfermo e inmigrante, no merece la pena".

26 De hecho, Faustino vive en una habitación alquilada: "Fui a pedir ayuda a un lugar en el que ofrecen asistencia a quienes no tienen casa donde vivir. Conseguí quedarme en ese centro ocho meses; al final, me marché y encontré una habitación, donde vivo hasta ahora".

${ }^{27}$ Como indica en su carta. 


\subsection{Mirando para otro lado: estar aquí, pero no ser de aquí}

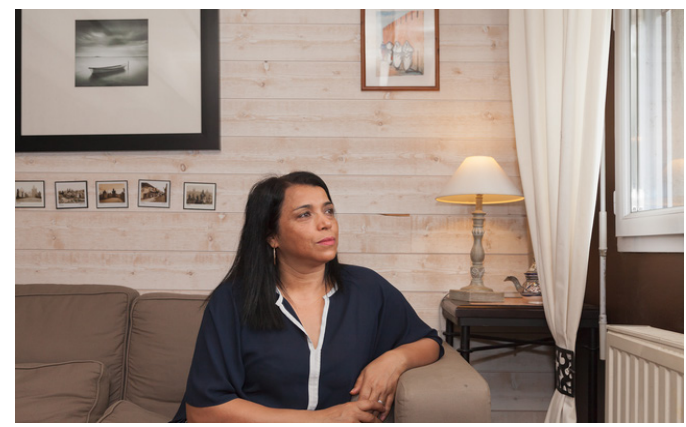

Hedia [I141] está en el salón de una casa. En la pared, hay una fotografía con una pequeña barca, vacía y varada en medio del mar, y otros cuadros y fotografías más pequeños relacionados con Túnez. También recuerdan a este país la chilaba con la que está vestida y la tetera que se haya encima de la mesa. Ella está sentada en la esquina de un sofá y mira, nostálgica, a la ventana cerrada que tiene una cortina plegada y que se encuentra a su lado. Por eso, aunque está cómodamente instalada y la casa no es pobre, Hedia parece algo ajena a su bienestar físico. De hecho, contempla el lado que está tras la ventana, signo quizás de su país de origen ${ }^{28}$, del que probablemente vino en barca y cuyos paisajes echa mucho de menos. En efecto, Túnez sigue muy presente en su vida, como constata toda la decoración de la estancia ${ }^{29}$, sin embargo, la ventana no está abierta, de modo que ella queda sola y encerrada con sus ensoñaciones, añoranzas y sentimientos más profundos, encerrada en una casa de aquí, pero que evoca la de allá.

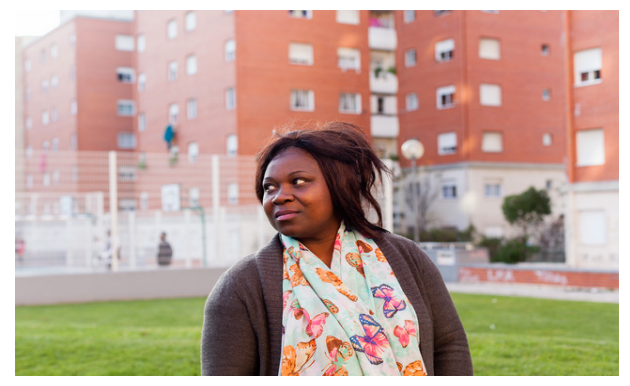

Evelize [I102] es una mujer de color que está en una urbanización de pisos, de acogida ${ }^{30}$, con césped y zona deportiva. Su rostro trasluce que en este edificio se encuentra bien, sin embargo, ella le da la espalda y mira hacia otro

28 "Cada vez que me marcho de Túnez, necesito unos días para acostumbrarme".

29 "Túnez nunca está lejos".

30 "En 2011 me realojaron, ahora tengo una casa social y pago un alquiler". 
lado, indiferente al lugar y a nosotros los espectadores, quizás porque siente nostalgia de ese otro territorio, lejano, y porque sueña jovialmente -sus ojos y su sonrisa, orientada hacia ese otro espacio, así lo desvelan- con lo que dejó atrás. Precisamente su camisa con mariposas de intenso colorido evoca ese otro sitio -que contrasta con la austeridad racionalista de la pared del inmueble-, tropical o subtropical, ¿Santo Tomé?

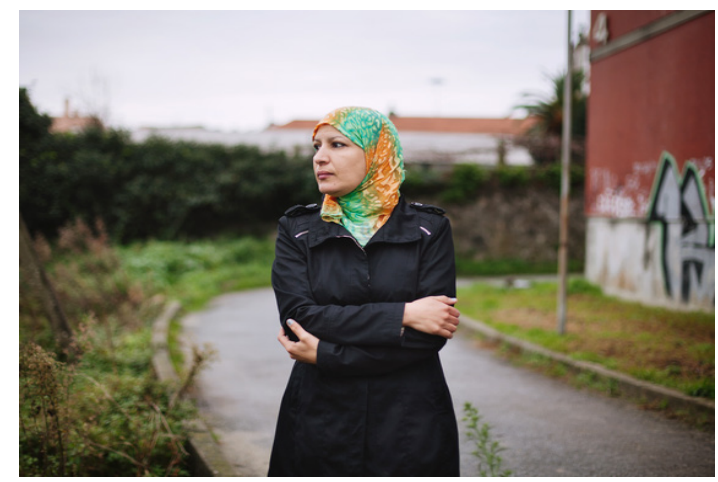

Fouzia [1118] anda, sola, por un camino que bordea un edificio con grafitis, que está difuminado, al igual que el resto de las construcciones. Está vestida con una gabardina de color negro que tapa casi completamente su cuerpo y porta un pañuelo de color en la cabeza -símbolo consciente de su tradición-. Mira hacia un lado distinto al del frente del camino por el que va, como si no importara el futuro, lo que está por venir, pero tampoco mira atrás ${ }^{31}$, como si estuviera en medio, en el margen entre el pasado y el futuro. Su desconcierto, su desubicación, se expresan mediante su mirada seria y triste, que la aíslan del entorno y de la realidad y que la introducen en un mundo onírico mental lleno de pensamientos y emociones que, una y otra vez, le recuerdan que ya no es ni de aquí ni de allí, pero, eso sí, -como expresa su abrazo a sí misma- que ahora ha alcanzado la autonomía personal ${ }^{32} \mathrm{y}$, por tanto, le queda la autoafirmación, el autoconsuelo y la autoayuda.

31 "Lo dejé todo atrás, hasta a mí misma"

${ }^{32}$ Tras la separación de su marido y su integración en el país de destino. 


\subsection{La soledad}

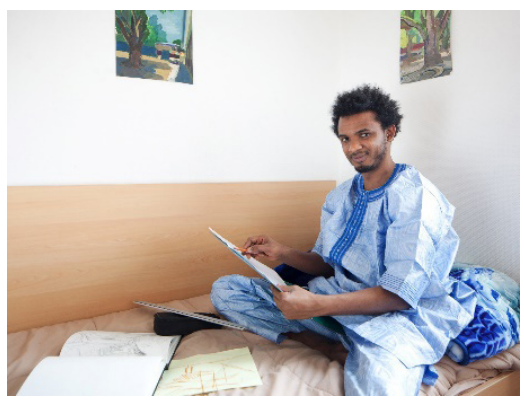

Como se ha visto, a excepción de tres fotografías, todos los retratados se muestran solos. Es también el caso de Kalil [I188], un joven pintor negro, que está sentado en un sofá sencillo con un cabezal de madera que él mismo parece haber construido. Los expresivamente coloridos dibujos de árboles que están en la pared, algo naïves, decoran una sobria y pobre pared blanca. Kalil está pintando y va vestido con un traje tradicional africano de un hermoso azul cielo, que -al igual que los cuadros- otorga algo de vida a esa habitación. Sin embargo, su pelo eléctrico, sus ojos bien abiertos y chispeantes, que no ocultan un aire de melancolía ${ }^{33}$, y sus carnosos labios, que dibujan una sonrisa inacabada, se contraponen dramáticamente a una apariencia de existencia naif. A ello se le suma que, en sus cuadros, no aparecen personas y que él mismo está solo ${ }^{34}$, en una estancia casi vacía.

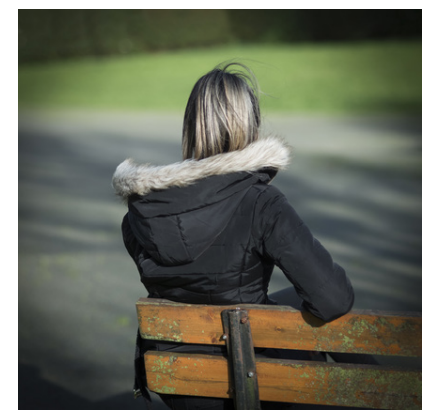

También Cristiane [I73] está sola, pero en una calle, sentada en la esquina de un banco descolorido en el que se apoya con un brazo y del que una pequeña parte del vestido o de ella misma se sale, como si, aunque no fuera perfecta su

33 "Os escribo con alegría y nostalgia".

${ }^{34}$ El sentimiento de soledad de Kalil es muy agudo: "Aprender a ser ignorado por el entorno. Es lo más doloroso, duele hasta la médula". 
vida actual ${ }^{35}$, se sintiera estable y segura en ella ${ }^{36}$. Aunque todo parece calmado, una ligera brisa o un suave movimiento de su cuerpo rompe la regularidad del peinado. La fotografía la presenta, por otra parte, de espaldas a nosotros y de ahí que no veamos ni sus ojos ni su rostro y, por consiguiente, no es fácil adivinar qué siente o qué estará pensando. Cierto, no es fácil saberlo, pero como quiera que lo que tiene delante está diluido, esto expresa que sus recuerdos se desvanecen con el paso del tiempo y que -como indica su pelo, ligeramente irregularuna liviana nostalgia la zozobra.

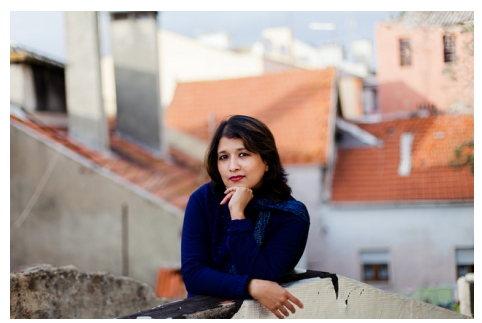

Hosna [I148] representa otra imagen de la soledad. Está en una terraza de un edificio. A ella se le ve muy bien, pero las azoteas de las otras casas del fondo se exhiben desvanecidas. Sin compañía ${ }^{37}$, su mirada es seria y -como indica la posición de su mano sobre la que apoya la barbilla- pensativa: ¿Tal vez recuerda con añoranza las tardes en las que se subía a la terraza de su casa del Magreb?

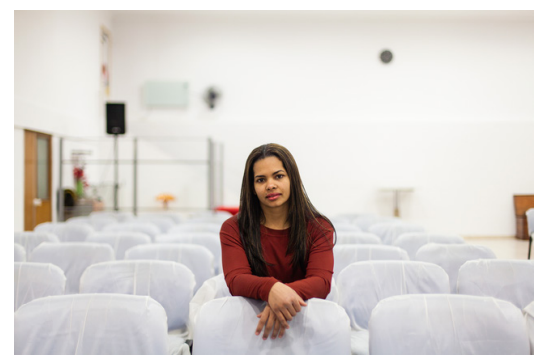

Elizângela [197] está en una sala con butacas, sentada en una de ellas, sola ${ }^{38}$, como si fuera una espectadora del mundo, pero no una actriz del mismo; como si su vida sucediese en un teatro del que no puede ser protagonista, en el que -como revelan sus brazos, cruzados pasivamente y apoyados en la butaca delantera- no logra hacer nada. Quizás, por eso, su rostro es serio, melancólico incluso, y nos mira directamente a los ojos, con valentía, tal vez para contarnos su no-historia, lo difícil que es ser migrante ${ }^{39}$, sin esperar nada a cambio.

35 "Siempre es difícil vivir lejos de nuestros seres queridos".

36 "La seguridad en las calles -de Francia- es mejor que en Brasil".

${ }^{37}$ A pesar de que vive con ella su esposo e hijos.

38 "Me sentía sola, sin nadie con quien hablar o incluso que me diera un abrazo. Era como si fuera un país depresivo".

39 "La vida en Portugal no es tan fácil como pensábamos y, para quien es inmigrante, todavía 


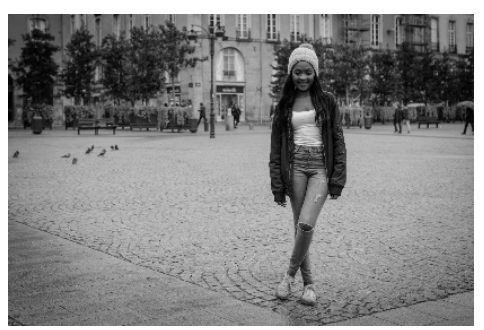

Como muestra el peculiar encuadre de esta fotografía, Lisa [I212] es una joven de color que está en un espacio público, sin embargo, ella conforma una intensa imagen de la soledad y de la indiferencia de los demàs y, al estar ubicada en el centro de la composición, nos hace pensar, y mucho, a los espectadores sobre ello. Lleva unos vaqueros rotos y unas zapatillas blancas algo gastadas, con unas cordoneras entrelazadas apresuradamente, signo de rapidez y movimiento. Está de pie, en medio de la plaza, justo en el centro de la esquina del empedrado, lejos de las personas, que parecen indiferentes, lo que refuerza su marginalidad, su desconfianza, su situación "irregular" ${ }^{\text {, }}$, su soledad y, en suma, la distancia emocional con el lugar y las personas en él dispuestas. Por lo demás, ella cruza las piernas, como buscando posar cómoda, pero es un gesto efímero y aparente, pues los pies no están plenamente instalados en el suelo, lo que hace pensar que podría descruzarlos en cualquier momento y salir apresuradamente del sitio ${ }^{41}$. Además, nos mira directamente, a lo que se suma que sus cejas están arqueadas, sus ojos no plenamente abiertos y que tiene arrugas en los párpados, como si le pesaran, como si no quisiera ver todo lo que podría mostrársele, o como si deseara protegerse de lo ya contemplado. También exhibe una sonrisa contenida, si no forzada, y congelada en un rictus artificial, manifestando todo ello su deseo de ser feliz donde se encuentra y la imposibilidad de serlo.

\section{CONCLUSIONES}

El análisis de las cartas y de las imágenes ha desvelado que la inmigración es un fenómeno además de diverso, profundamente ambivalente. Unos migrantes manifiestan percepciones negativas, mientras que otros se detienen en los aspectos positivos de su experiencia migratoria. Además, en un mismo migrante, mientras que su carta es más pesimista, la fotografía expresa lo contrario, o a la inversa. Por tanto, el proyecto migratorio, como uno de los momentos decisivos

se vuelve más difícil".

40 "Cada día vivir con el miedo y la angustia, porque verse en una situación irregular no es fácil. Todo tenemos que hacerlo con cuidado, porque al más mínimo fallo nos pueden pedir la identificación, con el corazón a cien por hora nada más ver un coche de policía... De verdad que es muy difícil vivir aquí como "inmigrante"”.

41 "...pero una se esfuerza por seguir avanzando y no abandonar nunca". 
en la vida, no está necesariamente asociado a un sentimiento de pérdida, sino que puede ser vivido como un tiempo de crecimiento personal, como una oportunidad vital, de libertad; como una experiencia que lleva a que puedas sentirte de muchos lugares distintos, a la vez de integrado en ellos. Además, las emociones y sentimientos de miedo, zozobra e incertidumbre no están ausentes, pero no son los predominantes entre los testimonios. Los rasgos positivos son los más reportados en las cartas, aunque la soledad y la nostalgia acompañan a la felicidad y al bienestar. Por consiguiente, nos encontramos ante una realidad compleja y poliédrica que queda amalgamada por la experiencia personal y la relación con el destino y con los seres queridos a los que se dirige la carta. La migración se presenta, pues, aquí como una de las muchas formas de socialización secundaria, de dinámica social que modifican a los sujetos (Martín Criado, 2014).

El análisis refleja también otra cuestión, a explorar más profundamente en el futuro con dispositivos metodológicos como el que presentamos en este artículo: el hecho de que la mirada tradicional hacia la migración ha resaltado fundamentalmente los avatares negativos de la misma, y destacado los prejuicios de la sociedad de acogida. Sin embargo, la mayoría de los testimonios recogidos aquí muestran una realidad bien diferente, basada en experiencias positivas, de crecimiento personal y de libertad, no exentas de esfuerzo y, en ocasiones, de sufrimiento.

La Enciclopedia de los Migrantes ha supuesto una nueva forma de cooperar de agentes diversos en la investigación, para crear un contenedor de conocimientos particulares extraídos de la experiencia de sus protagonistas y sin mediación alguna de los científicos sociales que participaron. Creemos, en este sentido, que la EM abre las puertas a la realización de numerosos análisis concretos sobre diferentes aspectos y que participa del conocimiento abierto, dejando que investigadores/as de todo el mundo puedan profundizar en el análisis de las cartas y de las imágenes.

\section{BIBLIOGRAFÍA}

AGUILAR IDÁÑNEZ, M. J. (2011): “Usos y aplicaciones de la Sociología Visual en el ámbito de las migraciones y la construcción de una ciudadanía intercultural", Tejuelo, 12, pp 100-135.

BARBOZA MARTÍNEZ, A. (2005): "Las imágenes como objeto y técnica de análisis en la Sociología: el método de la interpretación documental", en J. A. Roche Cárcel y M. Oliver Narbona (eds.), Cultura y globalización. Entre el conflicto y el diálogo, Alicante, Publicaciones de la Universidad de Alicante, pp. 347-366

BECKER, H. S. (1981): Exploring Society Photographically, Evanston, Illinois, Mary and Leigh Block Gallery, Northwestern University

BECKER, H. S. (1982): Art Worlds. Berkeley, University of California Press.

BELMONTE, C. (2007): "Emociones y cerebro", Rev. R. Acad. Cienc. Exact. Fís. Nat. 101(1), pp. 59-68. 
BELZUNEGUI, A.; BRUNET, I; PASTOR, I. (2012): "El diseño del Análisis Cualitativo Multinivel: una aplicación práctica para el análisis de entrevistas", Empiria. Revista de Metodología de Ciencias Sociales 23, pp. 15-44.

BERICAT, E. (2000): "La sociología de la emoción y la emoción en la sociología". Papers. Revista de Sociología, 62, pp. 145-176.

BERICAT, E. (2012): "Ciencias Sociales y cultura audiovisual: el conocimiento de la fotografía”, en J. A. Roche Cárcel (ed.), La Sociología como una de las Bellas Artes. La influencia de la literatura y de las artes en el pensamiento sociológico, Barcelona, Anthropos, pp. 201-224.

BOURDIEU, P. et al. (1965): Un art moyen: Essai sur les usages sociaux de la photographie, París, Les Éditions de Minuit.

CASANOVA CUBA, M. E. y MASSÓ GUIJARRO, B. (2018): “Aproximación a la crisis de los refugiados a través del titular y de la fotografía de prensa en España", Intersticios: Revista sociológica de pensamiento crítico, 12 (2), pp. 109-119.

CASSAIN, L. (2018): Trayectorias migratorias y procesos de retorno de España a Argentina, Tesis Doctoral, Madrid, Universidad Complutense.

DAMASIO, A. (1995): L'Erreur de Descartes. La Raison des Émotions, París, Éditions Odile Jacob.

DAMASIO, A. (2005): Spinoza avait raison, París, Éditions Odile Jacob.

DE ANDRÉS, S., NOS-ALDÁS, E. y GARCÍA-MATILLA, A. (2016): "La imagen transformadora. El poder de cambio social de una fotografía: la muerte de Aylan". Comunicar. Revista Científica de Educomunicación, 47, vol. XXIV, pp. 29-37.

DE MIGUEL, J. M. y PONCE DE LEON, O. (1998) : "Para una Sociología de la fotografía", REIS, 84/98, pp. 83-124.

DURAN, Ma . A. (2004): El dolor, la muerte y la memoria. Modelos sociales en la iconografía religiosa, Madrid, CSIC.

Documental El Tren de la Memoria (dirs. M. Arribas y A. Pérez). RTVE (2012). http:// www.rtve.es/alacarta/videos/el-documental/documental-tren-memoria/1797667/

GIDDENS, A. (1997): Modernidad e identidad del Yo. El Yo y la sociedad en la época contemporánea, Barcelona, Ediciones Península.

GOFFMAN, E. (1979): Gender Advertisement, Nueva York, Harper \& Row.

GONZÁLEZ GARCÍA, J. M. (1998): Sociología e iconología. REIS, Revista Española de Investigaciones Sociológicas, 84, pp. 23-43.

HOCHSCHILD, A. R. (1981): Power, Status and Emotion, Contemporary Sociology, 10, pp. 73-77.

HUICI URMENETA, V. y DAVILA LEGERÉN, A. (2019): "Fotografía y sociología en la era del zoon elektronikón”, Universitas Humanística, 87, pp. 143-168. https://doi. org/10.11144/Javeriana.uh87.fsez

KEMPER, TH. D. (1978): A Social Interactional Theory of Emotions, Nueva York, John Willey \& Sons.

KING, G., KEOHANE, R.O. y VERBA, S. (2000): El diseño de la investigación social. La inferencia científica en los estudios cualitativos, Madrid, Alianza Editorial.

LÓPEZ DEL RAMO, J. y HUMANES, M. L. (2016): “Análisis de contenido de la representación fotográfica de la crisis de los refugiados sirios y su incidencia en el framing visual", Scire, 22(2), pp. 87-97.

MARTÍN CRIADO, E. (2014): "Mentiras, inconsistencias y ambivalencias. Teoría de la acción y análisis del discurso", Revista Internacional de Sociología 72(1), pp. 115138 . 
MUÑIZ, C. et al (2006): "Imágenes de la inmigración a través de la fotografía de prensa. Un análisis de contenido", Comunicación y sociedad, XIX(1) pp. 103-128.

NUSSBAUM, M. C. (2014): Emociones políticas. ¿Por qué el amor es importante para la justicia?, Madrid, Paidós.

PANOFSKY, E. (1972): Estudios sobre iconología, Madrid, Alianza.

PANOFSKY, E. (2004): El significado en las artes visuales, Madrid, Alianza.

VAN DIJK, T. A. (1998): Ideología. Una aproximación multidisciplinaria, Barcelona, Gedisa. 